\title{
Distinct physiological responses of tomato and cucumber plants in silicon-mediated alleviation of cadmium stress
}

\section{OPEN ACCESS}

Edited by:

Raul Antonio Sperotto,

Centro Universitário Univates, Brazil

Reviewed by:

Felipe Klein Ricachenevsky,

Universidade Federal do Rio Grande

do Sul, Brazil

Weijun Zhou,

Zhejiang University, China

*Correspondence:

Haijun Gong,

College of Horticulture, Northwest

A\&F University, Yangling,

Shaanxi 712100, China

gongnavy@163.com

${ }^{\dagger}$ These authors have contributed

equally to this work.

Specialty section: This article was submitted to Plant Nutrition,

a section of the journal

Frontiers in Plant Science

Received: 14 March 2015

Accepted: 02 June 2015

Published: 16 June 2015

Citation:

Wu J, Guo J, Hu Y and Gong H

(2015) Distinct physiological responses of tomato and cucumber plants in silicon-mediated alleviation of cadmium stress.

Front. Plant Sci. 6:453. doi: 10.3389/fp/s.2015.00453

\author{
Jiawen $\mathrm{Wu}^{\dagger}$, Jia Guo ${ }^{\dagger}$, Yanhong Hu and Haijun Gong * \\ College of Horticulture, Northwest A\&F University, Yangling, Shaanxi, China
}

The alleviative effects of silicon (Si) on cadmium (Cd) toxicity were investigated in cucumber (Cucumis sativus L.) and tomato (Solanum lycopersicum L.) grown hydroponically. The growth of both plant species was inhibited by $100 \mu \mathrm{M} \mathrm{Cd}$, but $\mathrm{Si}$ application counteracted the adverse effects on growth. Si application significantly decreased the $\mathrm{Cd}$ concentrations in shoots of both species and roots of cucumber. The root-to-shoot transport of $\mathrm{Cd}$ was depressed by added $\mathrm{Si}$ in tomato whereas it was increased by added Si in cucumber. The total content of organic acids was decreased in tomato leaves but increased in cucumber roots and leaves by Si application under Cd stress. Si application also increased the cell wall polysaccharide levels in the roots of both species under Cd toxicity. Si-mediated changes in levels of organic acids and cell wall polysaccharides might contribute to the differences in Cd transport in the two species. In addition, Si application also mitigated $\mathrm{Cd}$-induced oxidative damage in both species. The results indicate that there were different mechanisms for Si-mediated decrease in shoot $\mathrm{Cd}$ accumulation: in tomato, Si supply decreased root-to-shoot Cd transport; whereas in cucumber, Si supply reduced the Cd uptake by roots. It is suggested that Si-mediated Cd tolerance is associated with different physiological responses in tomato and cucumber plants.

Keywords: antioxidant defense, cadmium, Cd transport, cell wall polysaccharide, organic acid, silicon

\section{Introduction}

In recent decades, extensive industrial and anthropogenic activities have caused serious heavy metal pollution. As a highly mobile and toxic element, cadmium (Cd) pollution is increasingly of concern. Cd toxicity can disturb morphological, biochemical and ultrastructural functions in plants (Ali et al., 2013, 2014). Although Cd does not participate in Fenton-type reaction directly, it can indirectly induce production of reactive oxygen species (ROS) such as superoxide radical $\left(\mathrm{O}_{2}{ }^{-}\right)$, hydrogen peroxide $\left(\mathrm{H}_{2} \mathrm{O}_{2}\right)$, and hydroxyl radical $(\bullet \mathrm{OH})$ (Stohs and Bagchi, 1995; Gonçalves et al., 2007). Excessive ROS production can disturb the balance of nutritional status and induce oxidative damage. What is more, $\mathrm{Cd}$ accumulation in crops and vegetables that exceeds the safety threshold will endanger human health via food chain (Aery and Rana, 2003; López-Millán et al., 2009).

Silicon ( $\mathrm{Si}$ ) is regarded as a beneficial element that is taken up by plant roots as silicic acid (Epstein, 1999). According to the modes of Si uptake, plants can be classified into three groups 
(active, passive, and exclusive uptake), and the corresponding plants are high, intermediate and low Si accumulators: examples are rice (Oryza sativa L.), cucumber (Cucumis sativus L.), and tomato (Solanum lycopersicum L.), respectively (Mitani and Ma, 2005). Many studies have shown that Si can alleviate heavy-metalinduced adverse effects on plant growth (Shi et al., 2005; Dragisic Maksimovic et al., 2012; Vaculík et al., 2012). It has been reported that, as a modulator of stress tolerance, $\mathrm{Si}$ exerts its beneficial roles mainly through two mechanisms: the protective effects of amorphous silica as a physical barrier, and the biochemical functions of aqueous silicic acid (Ma and Yamaji, 2008; Cooke and Leishman, 2011). The mechanism by which $\mathrm{Si}$ acts as a physical barrier has been well documented (Ma and Yamaji, 2008), whereas there is much less evidence for the direct biochemical function of $\mathrm{Si}$ in plants. Under Cd toxicity, Si application has been found to alleviate oxidative stress and affect root structure (Liang et al., 2005; Shi et al., 2005; Nwugo and Huerta, 2008, 2011; da Cunha and do Nascimento, 2009; Song et al., 2009; Liu et al., 2013b). However, the mechanism for Si-mediated Cd tolerance is still not fully understood, and the majority of previous studies have focused on cereal plants such as maize (Zea mays L.) and rice, which are high Si accumulators (Liang et al., 2005; Shi et al., 2005; Nwugo and Huerta, 2008, 2011; da Cunha and do Nascimento, 2009; Lukačová Kuliková and Lux, 2010; Liu et al., 2013a), where a physical blockage by Si deposition in these plants may have contributed to the decreased shoot $\mathrm{Cd}$ accumulation and therefore enhanced Cd tolerance (Shi et al., 2005). Up to date, relatively few papers have reported Si-alleviated $\mathrm{Cd}$ toxicity in vegetables, which are usually low $\mathrm{Si}$ accumulators (Shi et al., 2010; Farooq et al., 2013). Recently, Katz (2014) also pointed out the importance of studying $\mathrm{Si}$ accumulation and its function in non-grass species, with low capabilities of $\mathrm{Si}$ accumulation. In addition, the changes of $\mathrm{Cd}$ accumulation and translocation in plants due to $\mathrm{Si}$ addition reported in previous studies have been mixed. For example, previously, Song et al. (2009) found that Si addition decreased Cd uptake and transport in pakchoi. In maize, Vaculík et al. (2009) observed that addition of $\mathrm{Si}$ did not decrease the $\mathrm{Cd}$ concentration in the shoot and it even slightly increased the shoot $\mathrm{Cd}$ concentration at low $\mathrm{Cd}$ level. Therefore, the regulative role of Si on Cd uptake and transport in different plants still needs to be investigated, and investigation of the role of $\mathrm{Si}$ in less-Si-accumulating plants will help clarify the biochemical mechanism(s) of Si-mediated stress tolerance.

Cucumber and tomato are two important vegetables that suffer from $\mathrm{Cd}$ toxicity in areas with heavy-metal pollution (López-Millán et al., 2009; Feng et al., 2010). Reducing $\mathrm{Cd}$ accumulation in these vegetables is urgent to guarantee food safety. Compared with cereal crops, cucumber and tomato plants accumulate less Si. Using these low Siaccumulating plants as models should help clarify the possible biochemical mechanism of Si-mediated $\mathrm{Cd}$ tolerance in plants. However, to our knowledge, little information is available on the effects of $\mathrm{Si}$ on $\mathrm{Cd}$ toxicity in cucumber and tomato. Feng et al. (2010) found that Si could alleviate Cd-induced retardation of photosynthesis and nitrogen metabolism in cucumber, but Si-mediated alleviation of $\mathrm{Cd}$ toxicity in relation to $\mathrm{Cd}$ distribution and antioxidant defense remains to be investigated. In tomato, relevant information is lacking.

Organic acids can bind with heavy metals to form metalorganic acid complexes, which are involved in root-to-shoot transport of the metals in plants (Senden et al., 1995; Nigam et al., 2000; Han et al., 2006; Lu et al., 2013). Previous studies have shown that the plant organic acids concentrations are differently influenced by Cd toxicity (Boominathan and Doran, 2003; Tian et al., 2011; Xu et al., 2012; Lu et al., 2013). However, it remains unknown whether $\mathrm{Si}$ affects organic acid contents in a way that influences heavy metal transport in plants. On the other hand, the cell wall is the first barrier for stress defense in roots, and the number of functional groups $(-\mathrm{OH}$, $-\mathrm{COOH}$, and $-\mathrm{SH}$ ) in the cell wall components determines the capability of binding metal cations (Krzeslowska, 2011). Binding metal ions with the cell wall constituents can confine toxic metal to the walls and decrease their concentrations in the symplast (Krzeslowska, 2011; Yang et al., 2011). Liu et al. (2013a) observed Cd-Si co-complexation in the cell-wall matrix in rice suspension cells and protoplasts. Ma et al. (2015) further reported that the formation of [Si-hemicellulose matrix]Cd complexation in the rice cell walls contributed to the inhibition of Cd uptake. However, little information is available on the possible modulation of $\mathrm{Si}$ on the levels of cell wall constituents (such as pectin, hemicellulose, cellulose and lignin) under $\mathrm{Cd}$ toxicity.

Plants have evolved a complex defense system against ROS, consisting of enzymatic antioxidants such as superoxide dismutase (SOD), catalase (CAT), ascorbate peroxidase (APX) and glutathione reductase (GR), and non-enzymatic constituents such as non-protein thiol, ascorbic acid (AsA), glutathione (GSH) (Tiryakioglu et al., 2006). SOD can convert $\mathrm{O}_{2}{ }^{-}$to $\mathrm{H}_{2} \mathrm{O}_{2}$ and $\mathrm{O}_{2}$ while CAT is able to decompose $\mathrm{H}_{2} \mathrm{O}_{2}$ to $\mathrm{H}_{2} \mathrm{O}$ and $\mathrm{O}_{2}$ (Balakhnina and Borkowska, 2013). As key enzymes in ascorbate-glutathione cycle, APX and GR play important roles in scavenging excessive $\mathrm{H}_{2} \mathrm{O}_{2}$ in plants (Rennenberg, 1980). It has been observed that $\mathrm{Si}$ could alleviate $\mathrm{Cd}$ toxicity by enhancing antioxidant defense (Liu et al., 2013b). However, the possible role of antioxidant defense in Si-mediated alleviation of $\mathrm{Cd}$ toxicity in either tomato or cucumber has not been systematically investigated.

In this study, the effects of Si on Cd uptake, translocation and distribution, antioxidant defense, organic acids and cell wall components in cucumber and tomato under $\mathrm{Cd}$ stress were investigated, with the aim being to clarify the mechanisms for Si-mediated Cd tolerance in these plants contrasting in Siaccumulating capabilities.

\section{Materials and Methods}

\section{Plant Materials and Treatments}

Seeds of tomato (S. lycopersicum L. cv. Jinpengchaoguan) and cucumber (C. sativus L. cv. Xinyan No.7) were surface-sterilized with $10 \% \mathrm{H}_{2} \mathrm{O}_{2}$ for $15 \mathrm{~min}$ and germinated for 2 days at $25^{\circ} \mathrm{C}$ (tomato) or $28^{\circ} \mathrm{C}$ (cucumber) in the dark. Germinated 
seeds were transferred to a growth chamber $\left(25 / 15^{\circ} \mathrm{C}\right.$, day/night; $14 / 10 \mathrm{~h}$, light/dark, and relative humidity of $70 \%$ ) and uniform seedlings transplanted to 10 -L plastic pots when the third leaf was expanding.

The seedlings were grown in half-strength Hoagland solution which contained macro elements $(\mathrm{mM}): \mathrm{KNO}_{3} 2.5$, $\mathrm{Ca}\left(\mathrm{NO}_{3}\right)_{2} \cdot 4 \mathrm{H}_{2} \mathrm{O} 2.5, \mathrm{MgSO}_{4} \cdot 7 \mathrm{H}_{2} \mathrm{O} 1, \mathrm{KH}_{2} \mathrm{PO}_{4}$ 0.5; and micro elements $(\mu \mathrm{M}): \mathrm{H}_{3} \mathrm{BO}_{3} 46.1, \mathrm{MnCl}_{2} \cdot 4 \mathrm{H}_{2} \mathrm{O} 9.1, \mathrm{ZnSO}_{4} \cdot 7 \mathrm{H}_{2} \mathrm{O}$ 0.76, $\mathrm{CuSO}_{4} \cdot 5 \mathrm{H}_{2} \mathrm{O} \quad 0.32, \mathrm{Na}_{2} \mathrm{MoO}_{4} \cdot 2 \mathrm{H}_{2} \mathrm{O} \quad 0.24$. Iron was provided as EDTA-Fe at $50 \mu \mathrm{M}$. Before Cd stress, half of plants were pretreated for 2 weeks with $\mathrm{Si}$ as $\mathrm{Na}_{2} \mathrm{SiO}_{3} \cdot 9 \mathrm{H}_{2} \mathrm{O}(0.5$ and $2 \mathrm{mM}$ for cucumber and tomato, respectively). The solution $\mathrm{pH}$ was adjusted to 6.0 with $\mathrm{NaOH}$ or $\mathrm{HCl}$ solution. Additional $\mathrm{NaCl}$ was added to treatments without $\mathrm{Si}$ application to compensate the $\mathrm{Na}^{+}$introduced by $\mathrm{Si}$ supply. After Si pretreatment, the plants were subjected to $100 \mu \mathrm{M} \mathrm{CdCl} 2$ treatment without or with added Si. There were four treatments: control (CT, without $\mathrm{Si}$ or Cd treatment), $\mathrm{Si}, \mathrm{Cd}$, and $\mathrm{Si}+\mathrm{Cd}$. The nutrient solution was renewed every 3 days with continuous supply of air. After 15 days of $\mathrm{Cd}$ exposure, the plants were harvested for determinations.

\section{Determination of $\mathbf{C d}$ Concentration}

Plants were divided into shoots and roots. The roots were washed with distilled water at least three times, and were then immersed in ice-cold $0.5 \mathrm{mM} \mathrm{CaCl}_{2}$ for $20 \mathrm{~min}$, after which they were dried at $70^{\circ} \mathrm{C}$ for 3 days. Dry plant materials were ground to powder, weighed, and digested in mixed nitric acid-perchloric acid (v:v, 4:1) solution (Liu et al., 2013b). The Cd concentrations in digested solutions were determinate by atomic adsorption spectrophotometry (Hitachi Z-2000, Japan).

Root-to-shoot translocation factor $(T F)$ of $\mathrm{Cd}$ was calculated as follows:

$$
\mathrm{TF}=[\mathrm{Cd}]_{\text {shoot }} /[\mathrm{Cd}]_{\text {root }} \times 100 \%(\text { Shi et al., 2010). }
$$

\section{Fractionated Extraction of Cd}

Roots and laminae were fractionated according to Dragisic Maksimovic et al. (2012) with slight modifications. Briefly, tissues were infiltrated with $0.4 \mathrm{M}$ sucrose, then frozen with liquid nitrogen and homogenized first with $0.4 \mathrm{M}$ sucrose and then with $1 \%(\mathrm{w} / \mathrm{v})$ SDS. Each homogenate (sucrose and sucrose followed by SDS) was washed three times with the corresponding solutions (sucrose or SDS) and three times with distilled water. $\mathrm{Cd}$ extracted by sucrose represented weakly-bound symplastic Cd (sucrose extractable Cd) while extraction by SDS was symplastic $\mathrm{Cd}$ bound to the proteins (protein extractable $\mathrm{Cd}$ ), and the pellet was cell wall (cell wall bound $\mathrm{Cd}$ ).

\section{Si Concentration Determination}

Silicon in tissues was extracted with hydrochloric acid and hydrofluoric acid according to Heine et al. (2005) and Si concentrations were determined based on Dai et al. (2005). Briefly, the powders of dried tissues were incubated in a mixture of $1 \mathrm{M}$ hydrochloric acid and 2.3 M hydrofluoric acid (v:v, 1:2) for $24 \mathrm{~h}$. After incubation, the solutions were centrifuged and the supernatants were further incubated with $3.2 \%(\mathrm{w} / \mathrm{v})$ boric acid for another $24 \mathrm{~h}$. Aliquots of $10 \mathrm{~mL}$ ammonium molybdate tetrahydrate (54 $\mathrm{g} \mathrm{L}^{-1}, \mathrm{pH} 7.0$ ) was added into $1 \mathrm{~mL}$ of the supernatant. Five minutes later, $1 \mathrm{~mL}$ of reducing reagent consisted of solution $\mathrm{A}\left(0.2 \mathrm{~g} \mathrm{Na}_{2} \mathrm{SO}_{3}\right.$ and $0.4 \mathrm{~g} 1$ amino-2-naphthol-4-sulfonic acid in $25 \mathrm{~mL}$ of distilled water) and solution $\mathrm{B}\left(25 \mathrm{~g} \mathrm{NaHSO}_{3}\right.$ in $200 \mathrm{~mL}$ of distilled water) and $5 \mathrm{~mL} \mathrm{20 \% (w/v)} \mathrm{tartaric} \mathrm{acid} \mathrm{were} \mathrm{rapidly} \mathrm{added.} \mathrm{After}$ $30 \mathrm{~min}$ reaction, the supernatant were measured at absorbance at $650 \mathrm{~nm}$.

\section{Determination of Organic Acid Contents}

Tissues were extracted in $0.5 \mathrm{M} \mathrm{HCl}$ at $60^{\circ} \mathrm{C}$ for $1 \mathrm{~h}$, and then centrifuged at $8,000 \mathrm{~g}$ for $15 \mathrm{~min}$. After that, the supernatant was filtered through a $0.22 \mu \mathrm{M}$ millipore filter before organic acid analysis by high-performance liquid chromatography (HPLC, Waters, 1525, America). The mobile phase was $20 \mathrm{mM} \mathrm{KH}_{2} \mathrm{PO}_{4}(\mathrm{pH} 2.25)$ at a flow rate of $0.8 \mathrm{~mL}$ $\mathrm{min}^{-1}$, and the total run time was $35 \mathrm{~min}$. Organic acids were monitored at $210 \mathrm{~nm}$. The injection volume was $10 \mu \mathrm{L}$ and the concentration was calculated based on peak area (Xu et al., 2012).

\section{Root Cell Wall Isolation and Analysis}

Root tissues (about $3 \mathrm{~g}$ ) were ground into powder with liquid nitrogen, and the powder then immersed into $30 \mathrm{~mL}$ of cold ethanol. After $20 \mathrm{~min}$, the solution was centrifuged at $1,000 \mathrm{~g}$ for $20 \mathrm{~min}$, and the supernatant discarded. The pellet was washed with $20 \mathrm{~mL}$ of cold acetone, $20 \mathrm{~mL}$ of a mixture of methanol and chloroform $(1: 1 ; \mathrm{v} / \mathrm{v})$ and $20 \mathrm{~mL}$ of methanol successively, and the wash was conducted at least twice with each solution. The final pellet was dried with a freeze-dried (CS110-4, Scanvac, Denmark), and the dried pellet was regarded as cell wall (Zhong and Lauchli, 1993).

The constituents of cell wall were analyzed by fourier transform infrared spectroscopy analyzer (FTIR; Vetex 70, Bruker, Germany). Spectra were recorded from 1800 to $900 \mathrm{~cm}^{-1}$ with a resolution of $0.4 \mathrm{~cm}^{-1}$. Before detection, every sample was normalized with background scanning. The cell wall materials were mixed with dried $\mathrm{KBr}(1: 100)$ and ground with agate mortar and pestle, then the mixture was weighed and pressed with a tablet machine (no more than $10 \mathrm{KPa}$ ). The tablet was scanned with the FTIR (Regvar et al., 2013).

\section{8-Hydroxy-1, 3, 6-Pyrenetrisulphonic Acid (PTS) Uptake}

An apoplastic tracer, 8-hydroxy-1, 3, 6-pyrenetrisulphonic acid (abbreviated as PTS), was used to determine the apoplastic transport of Cd. Following $\mathrm{Si}$ pretreatment, the plants were subjected to $100 \mu \mathrm{M}$ Cd treatment in growth solution without or with $30 \mathrm{mg} \mathrm{L}^{-1}$ PTS for $24 \mathrm{~h}$. The shoots of six plants without PTS treatment and 12 plants with PTS treatment were harvested for fluorescence analysis. The shoots were extracted in deionized water at $90^{\circ} \mathrm{C}$ for $2 \mathrm{~h}$. PTS fluorescence was determined with an excitation wavelength of $403 \mathrm{~nm}$ and emission wavelength of $510 \mathrm{~nm}$ according to Gong 
et al. (2006) with a fluorescence spectrophotometer (Hitachi F-4600).

\section{Determination of TBARS and Hydrogen Peroxide $\left(\mathrm{H}_{2} \mathrm{O}_{2}\right)$ Contents}

Plant tissues $(0.5 \mathrm{~g})$ were homogenized in ice-cold $5 \%(\mathrm{w} / \mathrm{v})$ trichloroacetic acid (TCA) solution. After centrifugation at $3000 \mathrm{~g}$ for $10 \mathrm{~min}$, the supernatant was used to determine thiobarbituric acid reactive substances (TBARS) using the method of Heath and Packer (1968).

$\mathrm{H}_{2} \mathrm{O}_{2}$ contents were assayed according to Velikova et al. (2000). Potassium iodide (KI) was applied to detect $\mathrm{H}_{2} \mathrm{O}_{2}$ contents at an absorbance of $390 \mathrm{~nm}$.

\section{Determination of Membrane Stability Index (MSI)}

The third-oldest fresh leaves of tomato and cucumber seedlings were washed with deionized water and cut into leaf discs using a hole punch. Twenty discs were put into one clean glass tube with $10 \mathrm{~mL}$ of deionized water and evacuated for $10 \mathrm{~min}$ during which the tubes were shaken every $2 \mathrm{~min}$. Fresh roots $(0.2 \mathrm{~g})$ were weighed and also transferred into clean glass tube with $10 \mathrm{~mL}$ deionized water. Every treatment had two sets, and each set had four replicates. One set of the tubes with leaf discs or roots were heated at $40^{\circ} \mathrm{C}$ for $30 \mathrm{~min}$, and another set was heated at $100^{\circ} \mathrm{C}$ for $10 \mathrm{~min}$. After the solution cooled, its electrical conductivity was recorded (DDS-307 conductivity meter, Shanghai, China). The MSI was calculated as follows (Rodriguez-Hernandez et al., 2013):

MSI $=(1-\mathrm{C} 1 / \mathrm{C} 2) \times 100 \%$, where $\mathrm{C} 1$ and $\mathrm{C} 2$ represented the electrical conductivities of solutions in which the tissues were heated at $40^{\circ} \mathrm{C}$ and $100^{\circ} \mathrm{C}$, respectively.

\section{Antioxidant Enzyme Extraction and Activity Assays}

Plant tissues were homogenized in ice-cold $50 \mathrm{mM}$ potassium phosphate buffer solution ( $\mathrm{pH}$ 7.8) containing $0.2 \mathrm{mM}$ EDTA-Na 2 . After centrifugation at $12,000 \mathrm{~g}$ for $20 \mathrm{~min}$ at $4^{\circ} \mathrm{C}$, the supernatant was used to determine enzyme activities. Soluble protein contents were assayed by the method of Bradford (1976) using bovine serum albumin as a standard.

Superoxide dismutase and CAT activities were determined according to Dhindsa et al. (1981). Nitroblue tetrazolium (NBT) method was used for determination of SOD activity and one unit SOD activity was defined as the amount of enzyme required to cause a $50 \%$ inhibition of the rate of NBT reduction. The reaction mixture for CAT contained $25 \mathrm{mM}$ potassium phosphate buffer and $10 \mathrm{mM} \mathrm{H}_{2} \mathrm{O}_{2}$, and the reaction was initiated by addition of enzyme extract: the absorbance was determined at $240 \mathrm{~nm}$ after $180 \mathrm{~s}$.

Ascorbate peroxidase activity was measured based on the decrease of AsA content at $290 \mathrm{~nm}$ because AsA was oxidized by APX (Nakano and Asada, 1981). Determination of GR activity was based on the decrease of absorbance at $340 \mathrm{~nm}$ as NADPH was oxidized to NADP in the presence of GR enzyme (Fryer et al., 2002).

\section{Determination of Reduced Glutathione (GSH) and Ascorbic Acid Contents}

Glutathione content in plant tissues was determined according to Guri (1983) with slight modifications. Fresh tissue (1 g) was homogenized in $5 \mathrm{~mL}$ of $3 \%(\mathrm{w} / \mathrm{v})$ TCA containing $5 \mathrm{mM}$ EDTA in an ice bath, and the homogenate centrifuged at 4,000 $\mathrm{g}$ for $10 \mathrm{~min}$. Aliquots of $1 \mathrm{~mL}$ of the supernatant were titrated with about $0.2 \mathrm{~mL}$ of $1 \mathrm{M} \mathrm{NaOH}$ to adjust the $\mathrm{pH}$ to 6.5-7.0. Then $0.5 \mathrm{~mL}$ of $50 \mathrm{mM}$ K-phosphate buffer ( $\mathrm{pH} \mathrm{7.0)}$ and $0.05 \mathrm{~mL}$ of $1 \mathrm{mM}$ dithiobis-2-nitrobenzoic acid (DTNB) were added. After $5 \mathrm{~min}$ at room temperature, the absorbance at $412 \mathrm{~nm}$ was recorded. The GSH concentration was calculated using a standard curve.

Reduced AsA content in plant tissues was measured according to Arakawa et al. (1981) with small modifications. One gram of fresh tissue was homogenized in $5 \mathrm{~mL}$ of $5 \%(\mathrm{w} / \mathrm{v})$ TCA in an ice bath, and the homogenate centrifuged at $4,000 \mathrm{~g}$ for $10 \mathrm{~min}$. To $1 \mathrm{~mL}$ of the supernatant was added $1 \mathrm{~mL}$ of $5 \%(\mathrm{w} / \mathrm{v})$ TCA, $1 \mathrm{~mL}$ ethanol, $0.5 \mathrm{~mL}$ of $0.4 \%(\mathrm{v} / \mathrm{v}) \mathrm{H}_{3} \mathrm{PO}_{4}$-ethanol, $1 \mathrm{~mL}$ of $0.5 \%(\mathrm{w} / \mathrm{v})$ bathophenanthroline (BP)-ethanol, and $0.5 \mathrm{~mL}$ of $0.03 \%(\mathrm{w} / \mathrm{v}) \mathrm{FeCl}_{3}$-ethanol. The mixture was incubated at $30^{\circ} \mathrm{C}$ for $90 \mathrm{~min}$, and then the absorbance at $534 \mathrm{~nm}$ was recorded. The AsA content was determined using a standard curve.

\section{Statistical Analysis}

The data were analyzed by One-Way ANOVA or $t$-test. Comparison of data was subjected to LSD test at a significant level of 0.05 using SPSS software (SPSS Inc. 16.0).

\section{Results}

\section{Plant Growth}

Under non-stress conditions, Si addition had no obvious effect on the growth of tomato and cucumber plants (Figures 1A-D). Cd treatment significantly decreased the dry mass, leaf area and number in both tomato and cucumber (except the root dry weight in cucumber; Figures 1A-D). Under Cd toxicity, Si supply significantly increased these parameters (except the second leaf area of tomato, Figure 1C) and improved plant growth.

\section{Si Accumulation}

From our preliminary experiments, the optimum Si levels for Cd stress alleviation were 2 and $0.5 \mathrm{mM}$ for tomato and cucumber, respectively. Si concentrations in the shoot and roots were 2-3 times higher in Si-applied plants than in the corresponding controls (Table 1). Although the Si level for treating cucumber was only one fourth of that for tomato, the shoot $\mathrm{Si}$ concentrations were even higher in cucumber than in tomato (Table 1).

\section{Cd Accumulation and Subcellular Distribution}

The root-to-shoot Cd translocation was significantly higher in tomato than in cucumber (Table 2). Si application significantly decreased the shoot $\mathrm{Cd}$ concentrations in both tomato and cucumber (Table 2) and the root Cd concentration in cucumber. 


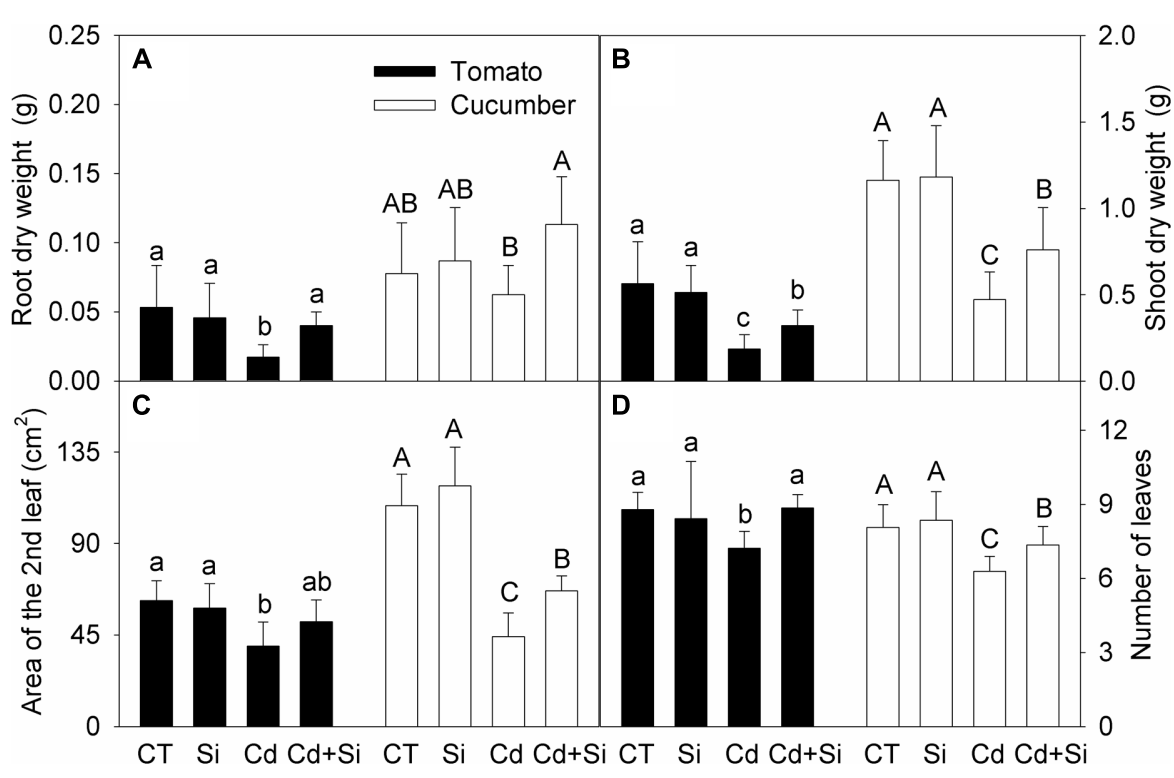

FIGURE 1 | Effects of silicon (Si) on dry weights of root (A) and shoot (B), the second leaf area (C) and total number of leaves (D) in tomato and cucumber plants under cadmium (Cd) stress. Bars with different letters means significant difference at $P<0.05$ according to one-way ANOVA. Lower-case and upper-case letters indicate significance for tomato and cucumber, respectively.

TABLE 1 | Silicon (Si) concentrations in tomato and cucumber as affected by $\mathrm{Cd}$ and $\mathrm{Si}$.

\begin{tabular}{|c|c|c|c|c|}
\hline \multirow{3}{*}{ Treatment } & \multicolumn{4}{|c|}{ Si concentration $\left(\mu \mathbf{g ~ g ^ { - 1 }} \mathrm{DW}\right)$} \\
\hline & \multicolumn{2}{|c|}{ Tomato } & \multicolumn{2}{|c|}{ Cucumber } \\
\hline & Shoot & Root & Shoot & Root \\
\hline CT & $710 \pm 219^{b}$ & $1170 \pm 292^{b}$ & $1447 \pm 456^{b}$ & $1621 \pm 378^{b}$ \\
\hline $\mathrm{Si}$ & $2324 \pm 624^{a}$ & $4005 \pm 643^{a}$ & $3520 \pm 552^{a}$ & $3315 \pm 604^{a}$ \\
\hline $\mathrm{Cd}$ & $803 \pm 108 b$ & $1922 \pm 543^{b}$ & $1071 \pm 114^{b}$ & $1440 \pm 104^{b}$ \\
\hline $\mathrm{Si}+\mathrm{Cd}$ & $2023 \pm 358^{a}$ & $4099 \pm 655^{a}$ & $3264 \pm 647^{a}$ & $3721 \pm 700^{a}$ \\
\hline
\end{tabular}

Data are means $\pm S D$. Values followed by different letters within a column represent significant difference at $P<0.05$ according to one-way ANOVA.

The root-to-shoot $\mathrm{Cd} T F$ was decreased by added $\mathrm{Si}$ in tomato, but increased in cucumber (Table 2).

In tomato, $\mathrm{Si}$ addition reduced the symplastic $\mathrm{Cd}$ in the leaves, whereas in the roots, it only decreased the sucrose extractable Cd concentration. In cucumber, Si supply decreased the concentrations of sucrose extractable and cell wall bound $\mathrm{Cd}$ in the leaves, and it decreased the Cd concentrations in all fractions in the roots (Table 3 ).

\section{Organic Acids Levels}

Five organic acids were detected in tomato and cucumber plants, with tartaric acid being the main organic acid in both plants (Tables 4 and 5).

In tomato roots, compared with the control, the tartaric acid concentration in Cd-stressed plants was not significantly changed, while the levels of the other four organic acids (especially malic acid) were considerably increased (Table 4). Under Cd stress, Si application enhanced the accumulation of tartaric acid and acetic acid while it decreased the levels of malic acid and citric acid. As a result, Si addition did not obviously change the total organic acids level under Cd stress (Table 4).

In tomato leaves, the tartaric acid concentration was significantly decreased under Cd stress, while the levels of other

TABLE 2 | Cadmium concentrations and translocation factors (TF) in tomato and cucumber grown hydroponically without or with added Si.

\begin{tabular}{|c|c|c|c|c|c|c|}
\hline \multirow{2}{*}{ Treatment } & \multicolumn{4}{|c|}{ Cd concentration $\left(\mu \mathrm{g} \mathrm{g}^{-1} \mathrm{DW}\right)$} & \multirow{2}{*}{\multicolumn{2}{|c|}{$\begin{array}{c}\text { TF (\%) } \\
\mathbf{C d}_{\text {shoot }} / \mathbf{C d}_{\text {root }}\end{array}$}} \\
\hline & \multicolumn{2}{|c|}{ Tomato } & \multicolumn{2}{|c|}{ Cucumber } & & \\
\hline $\mathrm{Cd}$ & $1136 \pm 125^{a}$ & $6931 \pm 893^{a}$ & $659 \pm 35.3^{a}$ & $13346 \pm 2069^{a}$ & $16.8 \pm 2.5^{\mathrm{a}}$ & $4.9 \pm 0.4^{b}$ \\
\hline $\mathrm{Si}+\mathrm{Cd}$ & $799 \pm 54.8^{b}$ & $6232 \pm 353^{a}$ & $550 \pm 24.2^{b}$ & $9486 \pm 1219^{b}$ & $13.0 \pm 0.5^{b}$ & $5.9 \pm 0.3^{a}$ \\
\hline
\end{tabular}

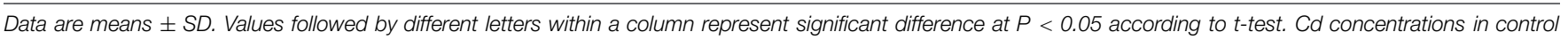
and Si treatments were undetected. 
TABLE 3 | Cadmium concentrations in different fractions extracted from the roots and leaves in tomato and cucumber plants.

\begin{tabular}{|c|c|c|c|c|c|c|c|}
\hline Species & Tissue & Treatment & $\begin{array}{l}\text { Sucrose extractable } \\
\left(\mu \mathrm{g} \mathrm{g}^{-1} \mathrm{FW}\right)\end{array}$ & $\begin{array}{l}\text { Protein bound } \\
\left(\mu \mathrm{g} \mathrm{g}^{-1} \mathrm{FW}\right)\end{array}$ & $\begin{array}{l}\text { Cell wall bound } \\
\left(\mu \mathrm{g} \mathrm{g}^{-1} \mathrm{FW}\right)\end{array}$ & $\begin{array}{l}\text { Total amount } \\
\left(\mu \mathrm{g} \mathrm{g}^{-1} \mathrm{FW}\right)\end{array}$ & $\begin{array}{l}\text { Percentage of cell } \\
\text { wall bound }(\%)\end{array}$ \\
\hline \multirow[t]{4}{*}{ Tomato } & Leaf & $\mathrm{Cd}$ & $36.2 \pm 1.3^{a}$ & $19.5 \pm 0.7^{a}$ & $8.1 \pm 0.7^{a}$ & $63.8 \pm 2.1^{a}$ & 12.7 \\
\hline & & $\mathrm{Si}+\mathrm{Cd}$ & $27.9 \pm 2.3^{b}$ & $10.6 \pm 0.4^{b}$ & $7.7 \pm 1.2^{\mathrm{a}}$ & $46.3 \pm 3.2^{b}$ & 16.6 \\
\hline & Root & $\mathrm{Cd}$ & $334.4 \pm 21.0^{\mathrm{a}}$ & $18.4 \pm 0.4^{a}$ & $262.8 \pm 40.6^{a}$ & $615.7 \pm 60.7^{a}$ & 42.7 \\
\hline & & $\mathrm{Si}+\mathrm{Cd}$ & $269.4 \pm 8.7^{b}$ & $15.1 \pm 2.7^{a}$ & $242.1 \pm 30.5^{a}$ & $526.6 \pm 47.4^{a}$ & 46.0 \\
\hline \multirow[t]{4}{*}{ Cucumber } & Leaf & $\mathrm{Cd}$ & $20.8 \pm 2.0^{\mathrm{a}}$ & $6.6 \pm 0.5^{a}$ & $12.5 \pm 0.8^{a}$ & $39.9 \pm 3.9^{\mathrm{a}}$ & 31.3 \\
\hline & & $\mathrm{Si}+\mathrm{Cd}$ & $14.1 \pm 0.3^{b}$ & $6.3 \pm 0.5^{a}$ & $7.0 \pm 1.1^{\mathrm{b}}$ & $27.3 \pm 1.5 b$ & 25.6 \\
\hline & Root & $\mathrm{Cd}$ & $535.3 \pm 20.1^{a}$ & $53.9 \pm 2.4^{a}$ & $334.2 \pm 50.6^{a}$ & $923.4 \pm 38.1^{a}$ & 36.2 \\
\hline & & $\mathrm{Si}+\mathrm{Cd}$ & $469.4 \pm 26.7^{b}$ & $38.2 \pm 3.1^{\mathrm{b}}$ & $217.3 \pm 13.8^{b}$ & $724.8 \pm 23.6^{b}$ & 30.0 \\
\hline
\end{tabular}

Data are means $\pm S D$. Values followed by different letters represent significant difference between $\mathrm{Cd}$ and $\mathrm{Si}+\mathrm{Cd}$ treatments within a species and tissue at $P<0.05$ according to t-test. Cd concentrations in control and Si treatments were undetected.

TABLE 4 | Effect of Si on organic acids concentrations in tomato seedlings under Cd toxicity.

\begin{tabular}{|c|c|c|c|c|c|c|c|}
\hline \multirow[b]{2}{*}{ Tissue } & \multicolumn{7}{|c|}{ Organic acid concentration $\left(\mu \mathrm{mol} \mathrm{g}{ }^{-1} \mathrm{FW}\right)$} \\
\hline & Treatment & Oxalic acid & Acetic acid & Tartaric acid & Citric acid & Malic acid & Total \\
\hline \multirow[t]{4}{*}{ Root } & CT & $5.98 \pm 0.16 b$ & $21.78 \pm 0.81^{d}$ & $722.9 \pm 10.4^{a b}$ & $3.94 \pm 0.18^{\mathrm{b}}$ & $0.63 \pm 0.04^{c}$ & $755.3 \pm 11.0^{\mathrm{a}}$ \\
\hline & Si & $7.66 \pm 0.23^{\mathrm{a}}$ & $28.48 \pm 0.97^{c}$ & $694.8 \pm 5.91^{b}$ & $4.25 \pm 0.33^{b}$ & $3.35 \pm 0.27^{b}$ & $738.5 \pm 7.1^{\mathrm{a}}$ \\
\hline & $\mathrm{Cd}$ & $7.99 \pm 0.75^{\mathrm{a}}$ & $39.04 \pm 1.70^{b}$ & $686.9 \pm 33.2^{b}$ & $5.42 \pm 0.20^{\mathrm{a}}$ & $11.11 \pm 1.23^{\mathrm{a}}$ & $750.5 \pm 32^{a}$ \\
\hline & $\mathrm{Si}+\mathrm{Cd}$ & $7.63 \pm 0.32^{\mathrm{a}}$ & $43.31 \pm 2.22^{a}$ & $746.2 \pm 11.0^{\mathrm{a}}$ & $2.55 \pm 0.27^{c}$ & $1.24 \pm 0.15^{c}$ & $800.9 \pm 8.6^{a}$ \\
\hline \multirow[t]{4}{*}{ Leaf } & $\mathrm{CT}$ & $35.47 \pm 0.40^{a}$ & $29.17 \pm 0.09^{b}$ & $1207 \pm 76^{a}$ & $7.53 \pm 0.27^{b}$ & $16.75 \pm 0.57^{c}$ & $1296 \pm 76.1^{a}$ \\
\hline & $\mathrm{Si}$ & $34.61 \pm 0.43^{b}$ & $22.84 \pm 0.74^{c}$ & $1017 \pm 32^{b}$ & $11.78 \pm 1.34^{a}$ & $16.19 \pm 0.62^{c}$ & $1102 \pm 31.9^{b}$ \\
\hline & $\mathrm{Cd}$ & $34.46 \pm 0.47^{\mathrm{b}}$ & $36.88 \pm 0.68^{a}$ & $965.7 \pm 4.88^{b}$ & $12.66 \pm 0.13^{a}$ & $31.09 \pm 0.85^{a}$ & $1080 \pm 3.34^{b}$ \\
\hline & $\mathrm{Si}+\mathrm{Cd}$ & $35.27 \pm 0.37^{a b}$ & $27.96 \pm 2.66^{b}$ & $760.5 \pm 27.2^{\mathrm{c}}$ & $13.26 \pm 1.23^{a}$ & $23.18 \pm 0.84^{b}$ & $860.1 \pm 28.7^{c}$ \\
\hline
\end{tabular}

Data are means $\pm S D$. Values followed by different letters within a column in a tissue represent significant difference among treatments at $P<0.05$ according to one-way ANOVA.

TABLE 5 | Effect of Si on organic acids concentrations in cucumber seedlings under Cd toxicity.

\begin{tabular}{|c|c|c|c|c|c|c|c|}
\hline \multirow[b]{2}{*}{ Tissue } & \multicolumn{7}{|c|}{ Organic acid concentration $\left(\mu \mathrm{mol} \mathrm{g}^{-1} \mathrm{FW}\right)$} \\
\hline & Treatment & Oxalic acid & Acetic acid & Tartaric acid & Citric acid & Malic acid & Total \\
\hline \multirow[t]{4}{*}{ Root } & CT & $1.00 \pm 0.05^{\mathrm{c}}$ & $17.11 \pm 0.38^{c}$ & $1058 \pm 35^{\mathrm{a}}$ & $1.54 \pm 0.24^{c}$ & $1.51 \pm 0.33$ & $1079 \pm 35.5^{\mathrm{a}}$ \\
\hline & $\mathrm{Si}$ & $0.92 \pm 0.01^{d}$ & $37.14 \pm 2.58^{a}$ & $922.1 \pm 11.6^{b}$ & $1.19 \pm 0.10^{c}$ & UD & $961.3 \pm 10.8^{b}$ \\
\hline & $\mathrm{Cd}$ & $1.13 \pm 0.03^{b}$ & $17.10 \pm 0.36^{c}$ & $608.5 \pm 10.3^{d}$ & $4.76 \pm 0.28^{b}$ & $2.47 \pm 0.39$ & $634.1 \pm 9.89^{d}$ \\
\hline & $\mathrm{Si}+\mathrm{Cd}$ & $2.12 \pm 0.05^{a}$ & $27.25 \pm 0.92^{b}$ & $688.4 \pm 11.6^{c}$ & $5.71 \pm 0.38^{a}$ & $2.73 \pm 0.14$ & $726.2 \pm 10.7^{c}$ \\
\hline \multirow[t]{4}{*}{ Leaf } & $\mathrm{CT}$ & ND & $17.72 \pm 1.24^{b}$ & $1388 \pm 9.2^{b}$ & $5.29 \pm 0.08^{a b}$ & $7.13 \pm 0.32^{\mathrm{c}}$ & $1418 \pm 19.6^{b}$ \\
\hline & $\mathrm{Si}$ & ND & $16.15 \pm 1.44 b$ & $1461 \pm 25.8^{a}$ & $5.09 \pm 0.58^{a}$ & $18.85 \pm 0.68^{a}$ & $1503 \pm 8.14^{a}$ \\
\hline & $\mathrm{Cd}$ & $2.91 \pm 0.23$ & $22.71 \pm 0.59^{a}$ & $707.4 \pm 6.34^{d}$ & $4.79 \pm 0.46^{b}$ & $13.88 \pm 0.74^{b}$ & $751.7 \pm 9.54^{d}$ \\
\hline & $\mathrm{Si}+\mathrm{Cd}$ & $2.33 \pm 0.14$ & $22.57 \pm 2.26^{a}$ & $805.8 \pm 6.83^{c}$ & $4.83 \pm 0.16^{b}$ & $14.32 \pm 0.36^{b}$ & $849.8 \pm 6.27^{c}$ \\
\hline
\end{tabular}

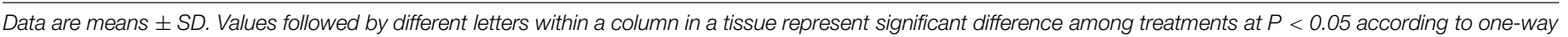
ANOVA. ND, not detected.

organic acids (except oxalic acid) were increased (Table 4). However, Si addition decreased the concentrations of tartaric acid, acetic acid, and malic acid in Cd-stressed plants. The concentrations of total organic acids were decreased under $\mathrm{Cd}$ stress, and they were further decreased by added $\mathrm{Si}$ in stressed plants (Table 4).

In cucumber roots, $\mathrm{Cd}$ toxicity induced a decrease in tartaric acids concentration and accumulations of malic acid and citric acid (Table 5). Under Cd stress, Si-treated plants had higher concentrations of tartaric acid, acetic acid, oxalic acid, and citric acid. The total organic acids level was increased by $\mathrm{Si}$ addition under Cd stress (Table 5).

In cucumber leaves, the tartaric acid concentration was dramatically decreased, while the levels of acetic acid, oxalic acid, and malic acid were increased under Cd stress (Table 5). Under Cd stress, Si supplement significantly increased the tartaric acid level, but it did not affect the contents of other organic acids (Table 5). 


\section{FTIR Spectra of Root Cell Walls}

The spectral peak intensities were higher in CT and Si treatments than in $\mathrm{Cd}$ and $\mathrm{Si}+\mathrm{Cd}$ treatments in both species (Figure 2). Under Cd toxicity, the following main peaks were decreased: at $1652 \mathrm{~cm}^{-1}$ representing amide I band from protein, at 1605$1590 \mathrm{~cm}^{-1}$ indicating carboxyl/acidic groups from pectin or aromatic systems (such as lignin, nitro groups); at $1545 \mathrm{~cm}^{-1}$ for stretching vibration $\mathrm{C}-\mathrm{N}$ and $\mathrm{C}-\mathrm{H}$ and/or bending vibration $\mathrm{N}-\mathrm{H}$

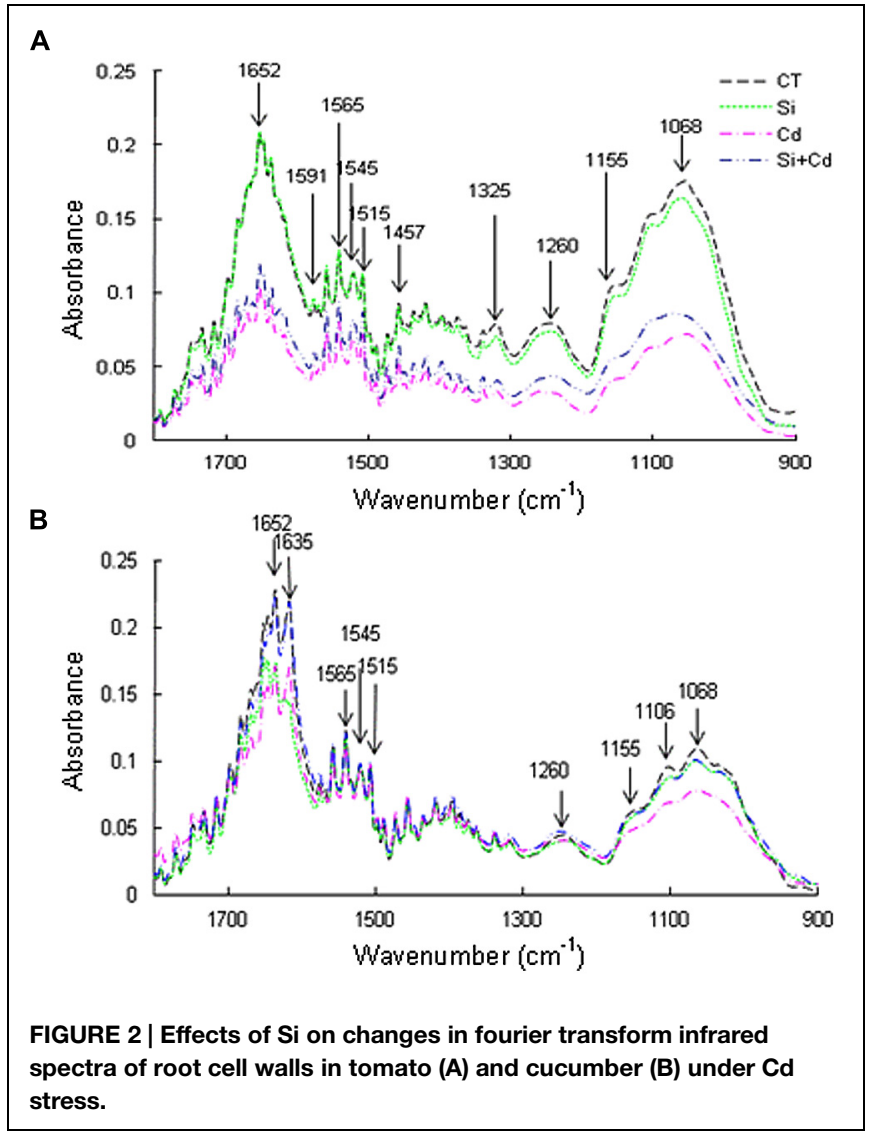

in protein (amide I band); at $1515 \mathrm{~cm}^{-1}$ for stretching $\mathrm{C}=\mathrm{C}$, $\mathrm{C}=\mathrm{O}$ and ring from lignin; at $1460-1400 \mathrm{~cm}^{-1}$ for alicyclic and aliphatic groups from lignin and/or various polysaccharides and carboxyl groups from pectin; at $1325 \mathrm{~cm}^{-1}$ for carboxyl groups from cellulosic compounds, ligands and protein; at $1300-1260 \mathrm{~cm}^{-1}$ for carboxyl groups from lignin, pectin, and various polysaccharides. The spectra between 900 and $1200 \mathrm{~cm}^{-1}$ represent the fingerprints of polysaccharides (Regvar et al., 2013; and references therein). In tomato roots, the spectral peak intensities were decreased under Cd stress, and the absorbance values were obviously higher in $\mathrm{Si}+\mathrm{Cd}$ treatment than $\mathrm{Cd}$ treatment, especially between 900 to $1300 \mathrm{~cm}^{-1}$ (Figure 2A). In cucumber roots, the absorbance values of spectra of the control, $\mathrm{Si}$ and $\mathrm{Si}+\mathrm{Cd}$ treatments were similar, while those of Cd treatment were obviously lower, especially at 1155,1105 , and $1068 \mathrm{~cm}^{-1}$, which indicates cellulosic compounds, pectin and hemicellulose, respectively (Figure $\mathbf{2 B}$ ).

\section{Apoplastic Transport of Cd}

8-hydroxy-1, 3, 6-pyrenetrisulphonic acid is a membraneimpermeable fluorescent dye, and it has been frequently used as an apoplastic tracer (Gong et al., 2006). In this study, after PTS treatment, no significant PTS fluorescence was observed above the background readings in the shoots of either tomato or cucumber (Figure 3). This suggests that there was no obvious Si-induced change of apoplastic transport in either tomato or cucumber. Therefore, there was no significant difference in $\mathrm{Cd}$ transport via the apoplast in the roots of $\mathrm{Cd}$ and $\mathrm{Cd}+\mathrm{Si}$ treatments in either plant species.

\section{MSI, TBARS Content and $\mathrm{H}_{2} \mathrm{O}_{2}$ Content}

Compared with the control, Cd toxicity resulted in an obvious decrease of MSI in the roots and leaves of tomato and cucumber seedlings. Si application significantly increased the MSI values under Cd stress, except in cucumber roots (Table 6).

Thiobarbituric acid reactive substances contents, which indicate lipid peroxidation, were significantly increased under $\mathrm{Cd}$ stress in the leaves and roots of both plants

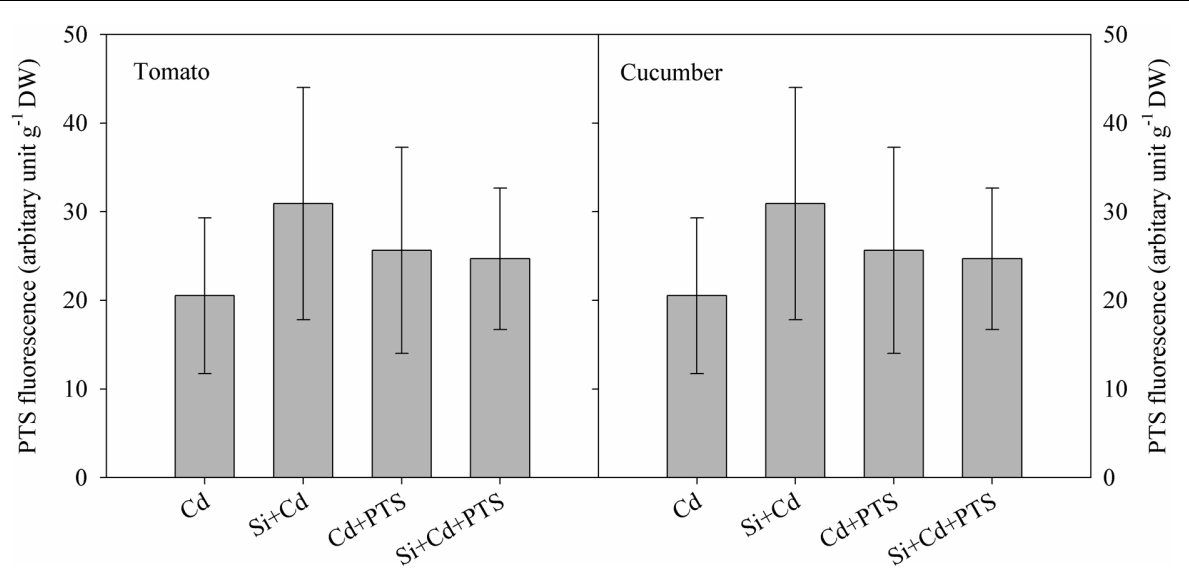

FIGURE 3 | Fluorescence of leaves as affected by Cd and PTS treatments. 
TABLE 6 | Effect of Si on membrane stability index (MSI) in tomato and cucumber under $\mathbf{C d}$ stress.

MSI (\%)

\begin{tabular}{llllll}
\cline { 2 - 3 } & \multicolumn{2}{c}{ Tomato } & & \multicolumn{2}{c}{ Cucumber } \\
\cline { 2 - 3 } \cline { 5 - 6 } Treatment & Leaf & Root & & Leaf & Root \\
\hline CT & $96.3 \pm 1.5^{\mathrm{a}}$ & $73.5 \pm 4.5^{\mathrm{a}}$ & & $94.9 \pm 1.2^{\mathrm{ab}}$ & $88.0 \pm 2.8^{\mathrm{a}}$ \\
$\mathrm{Si}$ & $95.5 \pm 0.8^{\mathrm{a}}$ & $78.4 \pm 3.7^{\mathrm{a}}$ & & $96.0 \pm 0.8^{\mathrm{a}}$ & $85.2 \pm 9.7^{\mathrm{ab}}$ \\
$\mathrm{Cd}$ & $80.1 \pm 1.1^{\mathrm{c}}$ & $54.7 \pm 3.9^{\mathrm{b}}$ & & $85.2 \pm 1.4^{\mathrm{c}}$ & $76.3 \pm 3.1^{\mathrm{b}}$ \\
$\mathrm{Si}+\mathrm{Cd}$ & $92.7 \pm 0.9^{\mathrm{b}}$ & $68.6 \pm 2.1^{\mathrm{a}}$ & & $94.0 \pm 0.8^{\mathrm{b}}$ & $84.7 \pm 4.0^{\mathrm{ab}}$ \\
\hline
\end{tabular}

Data are means $\pm S D$. Values followed by different letters within a column represent significant difference at $P<0.05$ according to one-way ANOVA.

(Figures 4A,B), and Si supply significantly decreased the contents (Figures 4A,B).

Cadmium stress induced significant increases of $\mathrm{H}_{2} \mathrm{O}_{2}$ concentrations in the leaves and roots of both plants (Figures 4C,D). Si addition had no impact on the $\mathrm{H}_{2} \mathrm{O}_{2}$ levels in non-stress conditions. Under $\mathrm{Cd}$ stress, added $\mathrm{Si}$ significantly decreased the $\mathrm{H}_{2} \mathrm{O}_{2}$ accumulation in tomato leaves and both leaves and roots of cucumber; whereas in tomato roots, $\mathrm{Si}$ addition had no significant effect on the $\mathrm{H}_{2} \mathrm{O}_{2}$ accumulation (Figure 4D).

\section{Activities of Antioxidant Enzymes}

According to Figures 5A-D, in tomato leaves, the activities of SOD and GR were depressed while the activities of CAT and APX were increased under Cd stress, and Si supply significantly increased the SOD activity but decreased the CAT, APX, and GR activities in stressed plants (Figures 5A-D). As can be seen from Figures $\mathbf{5 E}-\mathbf{H}$, in tomato roots, the activities of SOD and GR were decreased whereas the activities of CAT and APX were not significantly changed under Cd stress, and Si supply significantly increased the activities of these four enzymes.

As shown in Figures 5A-D, in cucumber leaves, the activities of CAT, APX, and GR were not significantly affected by Cd treatment, but the SOD activity was decreased; Si supply increased the activities of the four antioxidant enzymes under $\mathrm{Cd}$ stress. As can be seen from Figures $\mathbf{5 E}-\mathbf{H}$, in cucumber roots, the activities of all four enzymes were depressed under Cd stress, and Si supply significantly enhanced the activities of SOD, APX, and GR but did not affect the CAT activity.

\section{GSH and AsA Contents}

Compared with the control, Cd stress increased the GSH and AsA concentrations in the leaves and roots of both plants (Figures 6A-D). Under Cd stress, Si application further increased the GSH concentrations in tomato but did not affect the levels in cucumber (Figures 6A,B). By and large, except in cucumber roots, the AsA levels were decreased by $\mathrm{Si}$ application in $\mathrm{Cd}$ stressed plant tissues (Figures 6C,D).

\section{Discussion}

Cadmium contamination in agricultural land is a serious environmental problem. Its uptake by vegetable crops such as cucumber and tomato not only inhibits plant growth but also threatens human health. Therefore, minimizing $\mathrm{Cd}$ accumulation in these vegetables is urgent. $\mathrm{Si}$ is an element that can be massively accumulated in plants without

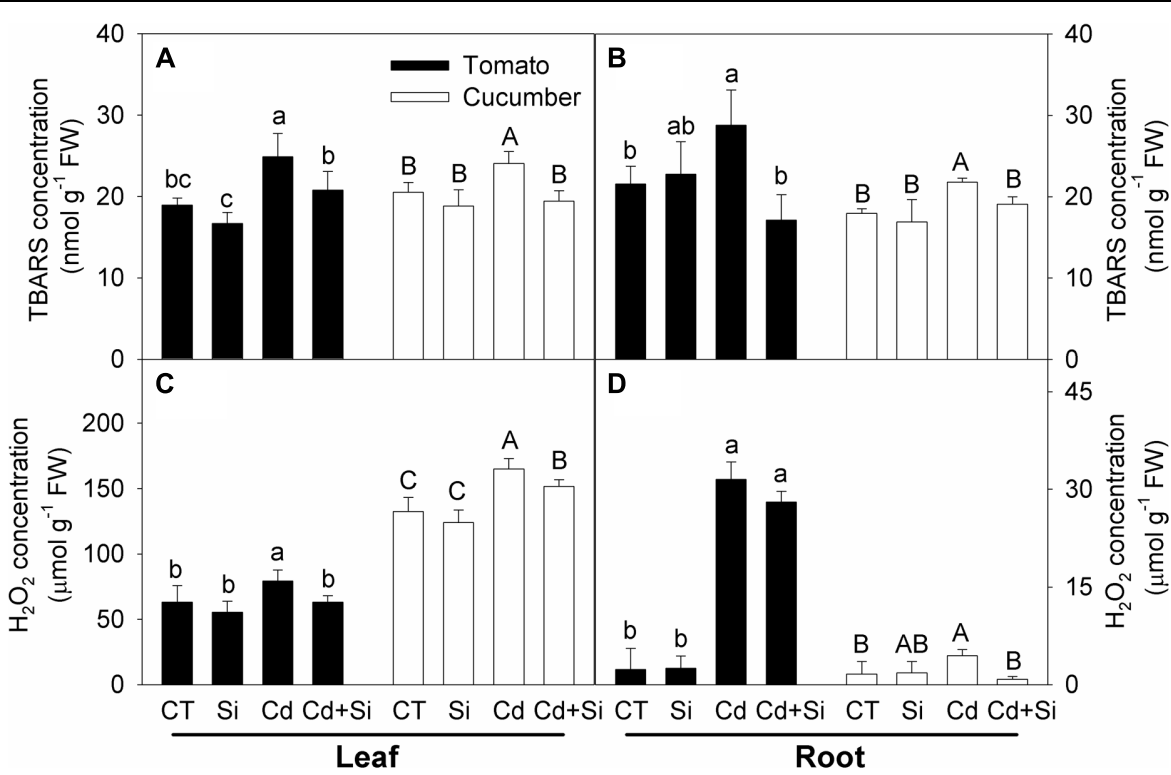

FIGURE 4 | Effects of $\mathrm{Si}$ on TBARS and $\mathrm{H}_{2} \mathrm{O}_{2}$ contents in leaves $(A, C)$ and roots (B,D) in tomato and cucumber under Cd stress. Bars with different letters means significant difference at $P<0.05$ according to one-way ANOVA (Lower-case and upper-case letters indicate significance for tomato and cucumber, respectively). TBARS, thiobarbituric acid reactive substances. 

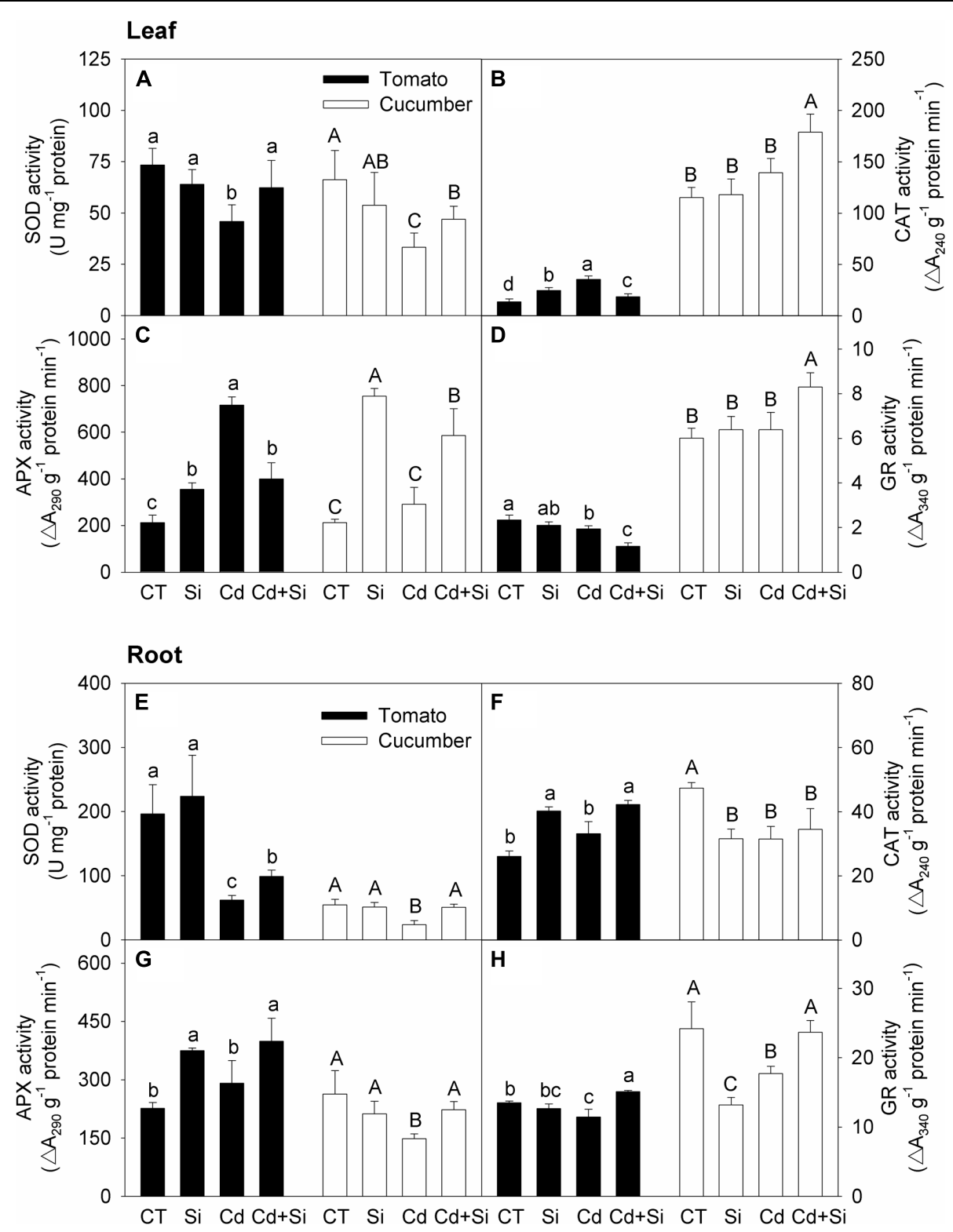

FIGURE 5 |Effects of $\mathrm{Si}$ on the activities of SOD (A,E), CAT $(B, F), \quad A P X(C, G)$ and $G R(D, H)$ in leaves (A-D) and roots $(E-H)$ in tomato and cucumber under $C d$ stress. Bars with different letters mean significant difference at $P<0.05$ according to one-way ANOVA (Lower-case and upper-case letters indicate significance for tomato and cucumber, respectively). SOD, superoxide dismutase; CAT, catalase; APX, ascorbate peroxidase; GR, glutathione reductase. toxic symptoms. Therefore, application of $\mathrm{Si}$ fertilizer may be an ideal means for sustainable development of agriculture. Si-mediated inhibition of $\mathrm{Cd}$ accumulation in cereal crops (Wu et al., 2013) also suggests a potential application of $\mathrm{Si}$ fertilizer in minimizing $\mathrm{Cd}$ pollution in vegetables.

It has been extensively reported that $\mathrm{Si}$ supplement can improve plant growth under Cd stress (Liang et al., 2007; Wu et al., 2013). However, there are few reports on the effect of Si on Cd toxicity in low-Si-accumulating plants, such as cucumber and tomato. Our results showed that the deleterious effects of
Cd toxicity could be mitigated by $\mathrm{Si}$ addition in both species (Figure 1). The alleviative effect of $\mathrm{Si}$ on plant growth under $\mathrm{Cd}$ stress may be related to the reduced $\mathrm{Cd}$ accumulation in both plants (Table 2). The beneficial Si effect in reducing $\mathrm{Cd}$ accumulation in the shoots of both species is very meaningful for vegetable safety and suggests a potential application of $\mathrm{Si}$ fertilizer in controlling $\mathrm{Cd}$ pollution of these vegetables. Siinduced decrease in shoot $\mathrm{Cd}$ accumulation has also been observed in other plants, such as rice (Shi et al., 2005), pakchoi (Song et al., 2009), wheat (Naeem et al., 2014), durum wheat (Rizwan et al., 2012), and maize (Liang et al., 2005). However, 


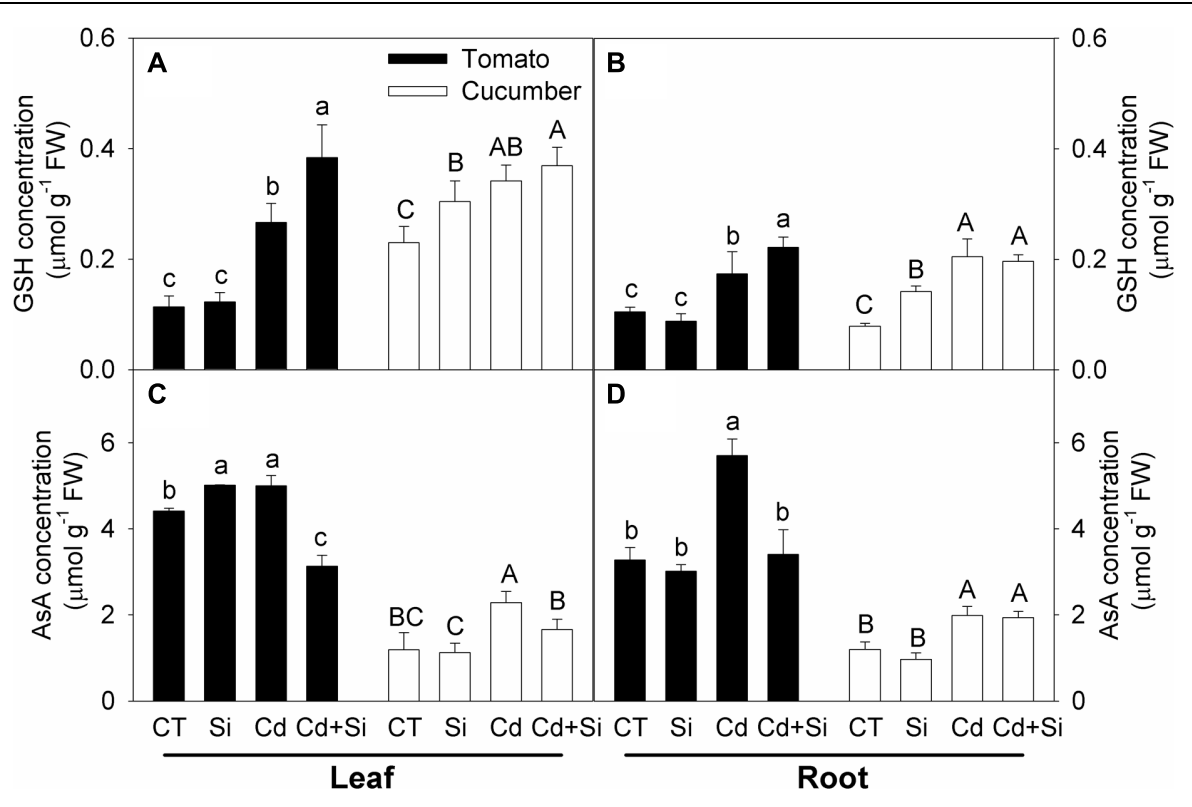

FIGURE 6 | Effects of Si on GSH (A,B) and AsA (C,D) contents in plants under Cd stress. (A) GSH content in leaves; (B) GSH content in roots; (C) AsA content in leaves; (D) AsA content in roots. Bars with different letters mean significant difference at $P<0.05$ according to one-way ANOVA (Lower-case and upper-case letters indicate significance for tomato and cucumber, respectively).

Vaculík et al. (2009) observed an increased shoot Cd level by Si application in maize. Lukačová et al. (2013) suggested that the $\mathrm{Si}$ effects on shoot $\mathrm{Cd}$ accumulation were related to $\mathrm{Cd}$ and $\mathrm{Si}$ concentrations in maize. These observed differences in silicon effects on shoot $\mathrm{Cd}$ accumulation may also be related to plant species. In roots, the effects of $\mathrm{Si}$ on $\mathrm{Cd}$ accumulation reported in the literatures have also been mixed, showing species- and cultivar-dependence (Song et al., 2009; Vaculík et al., 2009; Shi et al., 2010). Lukačová et al. (2013) suggested that the effect of $\mathrm{Si}$ on Cd accumulation in the roots of maize was associated with $\mathrm{Cd}$ and Si concentrations: at low $\mathrm{Cd}$ and Si concentrations, the root $\mathrm{Cd}$ level was increased by added $\mathrm{Si}$, whereas at high $\mathrm{Cd}$ and Si concentrations, $\mathrm{Si}$ addition decreased the Cd level in roots. Whether this is the case in tomato and cucumber remains to be investigated.

In our experimental conditions, the root-to-shoot $\mathrm{Cd}$ translocation was greater in tomato than in cucumber, suggesting a better restriction of $\mathrm{Cd}$ transport in cucumber. It is intriguing that compared with the control, Cd toxicity did not significantly affect the root dry weight of cucumber while it significantly decreased the root dry weight of tomato. This suggests that cucumber had better Cd tolerance than tomato based on the present study (Figure 1). However, a series of Cd concentrations and different cultivars should be used to further evaluate $\mathrm{Cd}$ tolerance difference between tomato and cucumber. Under Cd stress, Si application significantly decreased the root-to-shoot $\mathrm{Cd}$ translocation in tomato, whereas it increased the translocation in cucumber (Table 2). The reported effects of Si on root-to-shoot $\mathrm{Cd}$ translocation have been mixed in previous studies. Zhang et al. (2008) observed that Si supply decreased the root-to-shoot $\mathrm{Cd}$ translocation, which was consistent with our results in tomato
(Table 2). However, some researchers reported Si-enhanced Cd translocation in maize (Vaculík et al., 2009), and Brassinca juncea and B. napus (Vatehová et al., 2012). In peanut plants, Shi et al. (2010) observed that $\mathrm{Si}$ addition decreased root-to-shoot Cd translocation in the sensitive cultivar, but had no effect in the tolerant cultivar. These studies suggest that the effects of Si on Cd translocation may be species-, cultivar-, and Cd-concentrationdependent. In our study, since the $\mathrm{Cd}$ concentration in tomato roots was not changed by added $\mathrm{Si}$, the decrease of shoot $\mathrm{Cd}$ level is suggested to be attributed to Si-mediated decrease in root-to-shoot translocation. In cucumber plants, however, Si-mediated decrease in shoot $\mathrm{Cd}$ level might be attributed to decreased $\mathrm{Cd}$ uptake, rather than decreased root-to-shoot transport.

Organic acids have been found to be involved in heavy metal uptake, translocation and accumulation (Kramer et al., 2000; Boominathan and Doran, 2003; Küpper et al., 2004). In the xylem, metallic elements are transported as organic-metal co-complexation (Álvarez-Fernández et al., 2014). Salt et al. (1995) indicated that Cd was mainly coordinated with ligands containing sulfur in roots, and Cd predominately existed as Cdoxygen or Cd-nitrogen in the xylem sap which probably was Cd-organic acid. Sun et al. (2011) observed that there were positive correlations between $\mathrm{Cd}$ concentrations and tartaric or malic acids concentrations in the leaves of Rorippa globosa while the $\mathrm{Cd}$ concentrations were positively correlated with acetic acid concentrations in the leaves of $R$. islandica. Senden et al. (1995) reported that citric acid pretreatment could increase Cd uptake and translocation in tomato. Han et al. (2006) also observed enhanced Cd uptake and transport by exogenous acetic and malic acids in maize. It can be seen 
from these studies that organic acids can promote Cd uptake and translocation, with the major organic acid(s) being speciesdependant. However, up to date, reports concerning the $\mathrm{Si}$ effects on organic acid levels in plants are very limited. Pavlovic et al. (2013) found that Si could alleviate Fe deficiency in cucumber by enhancing the accumulation of Fe-mobilizing compounds (including citric acid and malic acid) in the roots. Bityutskii et al. (2014) also reported that Si supply could effectively alleviate Fe deficiency in cucumber, which was directly related to the increased levels of organic acids (especially citric acid) and phenolic compounds. These studies suggest that $\mathrm{Si}$ can regulate the metabolism of organic acids to affect $\mathrm{Fe}$ translocation. It will be interesting to investigate whether $\mathrm{Si}$ regulates $\mathrm{Cd}$ transport by modulating organic acids levels in plants.

In this study, under Cd stress, Si addition did not significantly change the levels of total organic acids in the roots of tomato, and it significantly decreased the levels in the leaves (Table 4); in cucumber plants, addition of Si significantly increased the levels of total organic acids in both roots and leaves (Table 5). The observed differences of Si-mediated changes in organic acid levels may be related to plant species. In tomato plants, the Si-mediated decrease of total organic acid levels in the leaves with no significant change in the roots might have contributed to the Si-mediated decrease in root-to-shoot $\mathrm{Cd}$ translocation (Table 2). In cucumber, Si-mediated increases of total organic acid levels in both roots and shoots might have facilitated Cd transport from the roots to the shoots (Table 2). To our knowledge, the effect of exogenous Si on organic acid levels under heavy metal stress has seldom been reported. Our results suggest that Si-mediated changes in levels of organic acids may be involved in $\mathrm{Cd}$ transport, which may help to elucidate the mechanisms for Si-mediated changes in heavy metal accumulation in the shoots. Further work is needed to elucidate how $\mathrm{Si}$ modulates the organic acids metabolism in plants.

Cellular distribution of heavy metal affects its toxicity in plants. The effects of Si on cellular distribution of heavy metal in plants have been investigated by previous researchers with mixed results. Shi et al. (2005) reported that, Si decreased Cd concentrations in rice shoots and roots, and reduced symplastic and apoplastic Cd levels. Under Mn toxicity, Si application decreased the Mn concentration in the symplast by locating more Mn into the apoplast (Rogalla and Römheld, 2002; Dragisic Maksimovic et al., 2012). In our study, Si supply decreased Cd concentrations in the symplast of leaves and roots in both plants (Table 3), which might have contributed to decreased oxidative stress under Cd stress as discussed below. However, the Si effects on $\mathrm{Cd}$ concentrations in the apoplast were different in the two species. The proportions of apoplastic $\mathrm{Cd}$ level in the roots and leaves were increased by added $\mathrm{Si}$ in tomato, but decreased by added $\mathrm{Si}$ in cucumber (Table 3 ). These changes were negatively related to the changes of Cd TFs, suggesting that the cell wall components might also affect Cd-binding capability, therefore root-to-shoot translocation. These studies also suggest that the effect of Si on cellular distribution of heavy metal is speciesdependent.
Cell walls play pivotal roles in regulating plant growth and defense strategies (Krzeslowska, 2011). Chen et al. (2013) reported that, under $\mathrm{Cd}$ toxicity, the contents of pectin and cellulose were positively correlated with $\mathrm{Cd}$ absorption, whereas hemicellulose content was negatively associated with $\mathrm{Cd}$ uptake. However, little information is available for Simediated alleviation of Cd toxicity in relation to cell wall components. In our study, under Cd stress, the spectrum peak intensities were dramatically decreased in tomato roots, while the decreases were much less in cucumber roots (Figure 2). These results are consistent with the changes of root dry weights under $\mathrm{Cd}$ stress and also suggest a better Cd tolerance of cucumber (Figure 1). Under Cd toxicity, Si addition increased the absorbance values of spectra in both species, especially between 900 and $1300 \mathrm{~cm}^{-1}$ where included cellulose $\left(1155 \mathrm{~cm}^{-1}\right)$, hemicellulose $\left(1068 \mathrm{~cm}^{-1}\right)$, and pectin $\left(1105 \mathrm{~cm}^{-1}\right)$ (Figure 2). The increase of root polysaccharide contents by $\mathrm{Si}$ addition in tomato was consistent with the increase in the proportion of apoplastic Cd (Table 3). However, a similar relationship did not exist in cucumber roots. In consideration of the complicated relationships between different polysaccharides and heavy metal uptake (Zheng et al., 2004; Yang et al., 2011; Chen et al., 2013), there is a possibility that the polysaccharide components and proportions in the two plants were different, and the polysaccharide components of Sienhanced synthesis were also different. However, in view of the observed differences in the roles of different polysaccharides or even the same polysaccharide by different researchers in $\mathrm{Cd}$ translocation (Zheng et al., 2004; Yang et al., 2011; Chen et al., 2013), more work is needed to clarify these speculations in future.

In rice, $\mathrm{Si}$ was mainly deposited in the vicinity of the endodermis, and the deposition partially blocked apoplastic $\mathrm{Cd}$ transport and therefore decreased shoot Cd concentration (Shi et al., 2005). In our study, PTS - an apoplastic tracer, was used to determine the apoplastic transport of Cd. However, there was no obvious difference in $\mathrm{Cd}$ transport via apoplastic pathway with or without added $\mathrm{Si}$ in either cucumber or tomato (Figure 3). These results suggest that, unlike rice, Si-deposition-induced physical blockage did not contribute to Si-mediated decrease in shoot $\mathrm{Cd}$ accumulation in either cucumber or tomato - two less-Si-accumulating plants.

Cadmium toxicity induced oxidative damage could be alleviated by enzymatic and non-enzymatic antioxidants in plants (Gonçalves et al., 2007). It is also widely accepted that $\mathrm{Si}$ application can ameliorate oxidative stress through regulating antioxidant enzyme activities and non-enzymatic antioxidant substance levels in plants (Liang et al., 2007; Wu et al., 2013). Song et al. (2009) reported that $\mathrm{Si}$ supply reduced the malonaldehyde and $\mathrm{H}_{2} \mathrm{O}_{2}$ contents under $\mathrm{Cd}$ stress by enhancing antioxidant enzyme activities and non-enzymatic antioxidant contents in pakchoi. Liu et al. (2013b) reported that Cd-toxicity-induced accumulations of malonaldehyde and $\mathrm{H}_{2} \mathrm{O}_{2}$ were decreased by added $\mathrm{Si}$, and the activities of antioxidant enzymes were also decreased. However, the possible role of antioxidant defense in Si-mediated alleviation of Cd toxicity in either tomato or cucumber has not been systematically investigated. In our work, 
Si supplement significantly mitigated lipid peroxidation and increased the MSI in leaves and roots of both tomato and cucumber seedlings (Figure 4, Table 6). These findings are consistent with previous studies (Song et al., 2009; Liu et al., 2013b). However, the changes in enzymatic and non-enzymatic constituents were different between cucumber and tomato. In cucumber, the $\mathrm{H}_{2} \mathrm{O}_{2}$ contents were decreased by added $\mathrm{Si}$ in leaves and roots under $\mathrm{Cd}$ treatment (Figures 4C,D), which might be related to enhanced antioxidant enzymes activities (Figure 5). In tomato leaves, Si application increased the SOD activity but decreased the activities of other antioxidant enzymes under Cd stress (Figure 5), indicating that the plants did not need high activities of antioxidant enzymes to scavenge excessive ROS in leaves because the $\mathrm{H}_{2} \mathrm{O}_{2}$ content in $\mathrm{Si}+\mathrm{Cd}$ treatment was at the control level (Figure 4C). However, in tomato roots, the $\mathrm{H}_{2} \mathrm{O}_{2}$ contents were similar with or without added $\mathrm{Si}$ under $\mathrm{Cd}$ toxicity (Figure 4D), and Si-mediated increases in antioxidant enzyme activities (Figure 5) and GSH concentration (Figure 6B) might be an adaptive response to counteract the stress. In consideration of the different responses of antioxidant enzymes activities in different tissues and species, it seems that Si modulated the antioxidant defense system as a secondary response. However, further work is needed to clarify this.

\section{References}

Aery, N. C., and Rana, D. K. (2003). Growth and cadmium uptake in barley under cadmium stress. J. Environ. Biol. 24, 117-123.

Ali, B., Huang, C. R., Qi, Z. Y., Ali, S., Daud, M. K., Geng, X. X., et al. (2013). 5-Aminolevulinic acid ameliorates cadmium-induced morphological, biochemical, and ultrastructural changes in seedlings of oilseed rape. Environ. Sci. Pollutn. Res. 20, 7256-7267. doi: 10.1007/s11356-013-1735-5

Ali, B., Qian, P., Jin, R., Ali, S., Khan, M., Aziz, R., et al. (2014). Physiological and ultra-structural changes in Brassica napus seedlings induced by cadmium stress. Biol. Plantarum 58, 131-138.

Álvarez-Fernández, A., Díaz-Benito, P., Abadía, A., Lopez-Millan, A.-F., and Abadía, J. (2014). Metal species involved in long distance metal transport in plants. Front. Plant Sci. 5:105. doi: 10.3389/fpls.2014.00105

Arakawa, N., Tsutsumi, K., Sanceda, N. G., Kurata, T., and Inagaki, C. (1981). A rapid and sensitive method for the determination of ascorbic acid using 4,7-diphenyl-1,10-phenanthroline. Agric. Biol. Chem. 45, 1289-1290. doi: 10.1271/bbb1961.45.1289

Balakhnina, T., and Borkowska, A. (2013). Effects of silicon on plant resistance to environmental stresses: review. Int. Agrophys. 27, 225-232. doi: 10.2478/v10247-012-0089-4

Bityutskii, N., Pavlovic, J., Yakkonen, K., Maksimovic, V., and Nikolic, M. (2014). Contrasting effect of silicon on iron, zinc and manganese status and accumulation of metal-mobilizing compounds in micronutrientdeficient cucumber. Plant Physiol. Biochem. 74, 205-211. doi: 10.1016/j.plaphy.2013.11.015

Boominathan, R., and Doran, P. M. (2003). Organic acid complexation, heavy metal distribution and the effect of ATPase inhibition in hairy roots of hyperaccumulator plant species. J. Biotechnol. 101, 131-146. doi: 10.1016/S0168-1656(02)00320-6

Bradford, M. M. (1976). A rapid and sensitive method for the quantitation of microgram quantities of protein utilizing the principle of proteindye binding. Anal. Biochem. 72, 248-254. doi: 10.1016/0003-2697(76) 90527-3

Chen, G., Liu, Y., Wang, R., Zhang, J., and Owens, G. (2013). Cadmium adsorption by willow root: the role of cell walls and their subfractions. Environ. Sci. Pollut. Res. 20, 5665-5672. doi: 10.1007/s11356-013-1506-3

\section{Conclusion}

Silicon could alleviate Cd-induced growth inhibition in tomato and cucumber. The alleviation was related to the decreased $\mathrm{Cd}$ accumulation in the shoot. In tomato, the decreased $\mathrm{Cd}$ concentration is suggested to be attributed to Si-mediated decrease in root-to-shoot translocation; whereas in cucumber, Si-mediated decrease in shoot $\mathrm{Cd}$ level might be attributed to decreased $\mathrm{Cd}$ uptake by roots. Si could modulate the organic acid levels and cell wall components, which might be involved in Cd transport regulation in both plants. Si-mediated alleviation of oxidative damage also contributed to $\mathrm{Cd}$ tolerance in both species.

\section{Acknowledgments}

We thank Professor Timothy J. Flowers from University of Sussex (UK) for revising the language. This study is supported by National Natural Science Foundation of China (31272152, 31471866), Program for New Century Excellent Talents in University of China (NCET-11-0441) and Research Fund for the Doctoral Program of Higher Education of China (20120204110020).

Cooke, J., and Leishman, M. R. (2011). Is plant ecology more siliceous than we realise? Trends Plant Sci. 16, 61-68. doi: 10.1016/j.tplants.2010.10.003

da Cunha, K. P. V., and do Nascimento, C. W. A. (2009). Silicon effects on metal tolerance and structural changes in maize (Zea mays L.) grown on a cadmium and zinc enriched soil. Water Air Soil Poll. 197, 323-330. doi: 10.1007/s11270-008-9814-9

Dai, W., Zhang, K., Duan, B., Sun, C., Zheng, K., Cai, R., et al. (2005). Rapid determination of silicon content in rice. Rice Sci. 12, 145-147.

Dhindsa, R. S., Plumb-Dhindsa, P., and Thorpe, T. A. (1981). Leaf senescence: correlated with increased levels of membrane permeability and lipid peroxidation, and decreased levels of superoxide dismutase and catalase. J. Exp. Bot. 32, 93-101. doi: 10.1093/jxb/32.1.93

Dragisic Maksimovic, J., Mojovic, M., Maksimovic, V., Romheld, V., and Nikolic, M. (2012). Silicon ameliorates manganese toxicity in cucumber by decreasing hydroxyl radical accumulation in the leaf apoplast. J. Exp. Bot. 63, 2411-2420. doi: 10.1093/jxb/err359

Epstein, E. (1999). Silicon. Annu. Rev. Plan.t Physiol. Plant Mol. Biol. 50, 641-664. doi: 10.1146/annurev.arplant.50.1.641

Farooq, M. A., Ali, S., Hameed, A., Ishaque, W., Mahmood, K., and Iqbal, Z. (2013). Alleviation of cadmium toxicity by silicon is related to elevated photosynthesis, antioxidant enzymes; suppressed cadmium uptake and oxidative stress in cotton. Ecotoxicol. Environ. Saf. 96, 242-249. doi: 10.1016/j.ecoenv.2013. 07.006

Feng, J., Shi, Q., Wang, X., Wei, M., Yang, F., and Xu, H. (2010). Silicon supplementation ameliorated the inhibition of photosynthesis and nitrate metabolism by cadmium (Cd) toxicity in Cucumis sativus L. Sci. Hortic. 123, 521-530. doi: 10.1016/j.scienta.2009.10.013

Fryer, M. J., Oxborough, K., Mullineaux, P. M., and Baker, N. R. (2002). Imaging of photo-oxidative stress responses in leaves. J. Exp. Bot. 53, 1249-1254. doi: 10.1093/jexbot/53.372.1249

Gonçalves, J. F., Becker, A. G., Cargnelutti, D., Tabaldi, L. A., Pereira, L. B., Battisti, V., et al. (2007). Cadmium toxicity causes oxidative stress and induces response of the antioxidant system in cucumber seedlings. Braz. J. Plant Physiol. 19, 223-232. doi: 10.1590/S1677-04202007000300006

Gong, H. J., Randall, D. P., and Flowers, T. J. (2006). Silicon deposition in the root reduces sodium uptake in rice (Oryza sativa L.) seedlings by reducing bypass flow. Plant Cell Environ. 29, 1970-1979. doi: 10.1111/j.1365-3040.2006.01572.x 
Guri, A. (1983). Variation in glutathione and ascorbic acid content among selected cultivars of phaseolus vulgaris prior to and after exposure to ozone. Can. J. Plant Sci. 63, 733-737. doi: 10.4141/cjps83-090

Han, F., Shan, X., Zhang, S., Wen, B., and Owens, G. (2006). Enhanced cadmium accumulation in maize roots-the impact of organic acids. Plant Soil 289, 355-368. doi: 10.1007/s11104-006-9145-9

Heath, R. L., and Packer, L. (1968). Photoperoxidation in isolated chloroplasts: I. Kinetics and stoichiometry of fatty acid peroxidation. Arch. Biochem. Biophys. 125, 189-198. doi: 10.1016/0003-9861(68)90654-1

Heine, G., Tikum, G., and Horst, W. J. (2005). Silicon nutrition of tomato and bitter gourd with special emphasis on silicon distribution in root fractions. J. Plant Nutr. Soil Sc. 168, 600-606. doi: 10.1002/jpln.200420508

Katz, O. (2014). Beyond grasses: the potential benefits of studying silicon accumulation in non-grass species. Front. Plant Sci. 5:376. doi: 10.3389/fpls.2014.00376

Kramer, U., Pickering, I. J., Prince, R. C., Raskin, I., and Salt, D. E. (2000). Subcellular localization and speciation of nickel in hyperaccumulator and non-accumulator Thlaspi species. Plant Physiol. 122, 1343-1353. doi: 10.1104/pp.122.4.1343

Krzeslowska, M. (2011). The cell wall in plant cell response to trace metals: polysaccharide remodeling and its role in defense strategy. Acta Physiol. Plant 33, 35-51. doi: 10.1007/s11738-010-0581-z

Küpper, H., Mijovilovich, A., Meyer-Klaucke, W., and Kroneck, P. M. (2004). Tissue- and age-dependent differences in the complexation of cadmium and zinc in the cadmium/zinc hyperaccumulator Thlaspi caerulescens (Ganges ecotype) revealed by x-ray absorption spectroscopy. Plant Physiol. 134, 748757. doi: 10.1104/pp.103.032953

Liang, Y., Sun, W., Zhu, Y. G., and Christie, P. (2007). Mechanisms of siliconmediated alleviation of abiotic stresses in higher plants: a review. Environ. Pollut. 147, 422-428. doi: 10.1016/j.envpol.2006.06.008

Liang, Y., Wong, J. W., and Wei, L. (2005). Silicon-mediated enhancement of cadmium tolerance in maize (Zea mays L.) grown in cadmium contaminated soil. Chemosphere 58, 475-483. doi: 10.1016/j.chemosphere.2004. 09.034

Liu, J., Ma, J., He, C., Li, X., Zhang, W., Xu, F., et al. (2013a). Inhibition of cadmium ion uptake in rice (Oryza sativa) cells by a wall-bound form of silicon. New Phytol. 200, 691-699. doi: 10.1111/nph.12494

Liu, J., Zhang, H., Zhang, Y., and Chai, T. (2013b). Silicon attenuates cadmium toxicity in Solanum nigrum L. by reducing cadmium uptake and oxidative stress. Plant Physiol. Biochem. 68, 1-7. doi: 10.1016/j.plaphy.2013.03.018

López-Millán, A. F., Sagardoy, R., Solanas, M., Abadía, A., and Abadía, J. (2009). Cadmium toxicity in tomato (Lycopersicon esculentum L.) plants grown in hydroponics. Environ. Exp. Bot. 65, 376-385. doi: 10.1016/j.envexpbot.2008.11.010

Lu, L. L., Tian, S. K., Yang, X. E., Peng, H. Y., and Li, T. Q. (2013). Improved cadmium uptake and accumulation in the hyperaccumulator Sedum alfredii: the impact of citric acid and tartaric acid. J. Zhejiang Univ. Sci. B 14, 106-114. doi: 10.1631/jzus.B1200211

Lukačová Kuliková, Z., and Lux, A. (2010). Silicon influence on maize, Zea mays L., hybrids exposed to cadmium treatment. Bull. Environ. Contam. Toxicol. 85, 243-250. doi: 10.1007/s00128-010-0046-5

Lukačová, Z., Švubová, R., Kohanová, J., and Lux, A. (2013). Silicon mitigates the $\mathrm{Cd}$ toxicity in maize in relation to cadmium translocation, cell distribution, antioxidant enzymes stimulation and enhanced endodermal apoplasmic barrier development. Plant Growth Regul. 70, 89-103. doi: 10.1007/s10725-012-9781-4

Ma, J., Cai, H., He, C., Zhang, W., and Wang, L. (2015). A hemicellulose-bound form of silicon inhibits cadmium ion uptake in rice (Oryza sativa) cells. New Phytol. 206, 1063-1074. doi: 10.1111/nph.13276

Ma, J. F., and Yamaji, N. (2008). Functions and transport of silicon in plants. Cell Mol. Life Sci. 65, 3049-3057. doi: 10.1007/s00018-008-7580-x

Mitani, N., and Ma, J. F. (2005). Uptake system of silicon in different plant species. J. Exp. Bot. 56, 1255-1261. doi: 10.1093/jxb/eri121

Naeem, A., Saifullah, U., Ghafoor, A., and Farooq, M. (2014). Suppression of cadmium concentration in wheat grains by silicon is related to its application rate and cadmium accumulating abilities of cultivars. J. Sci. Food Agric. doi: 10.1002/jsfa.6976 [Epub ahead of print].

Nakano, Y., and Asada, K. (1981). Hydrogen peroxide is scavenged by ascorbatespecific peroxidase in spinach chloroplasts. Plant Cell Physiol. 22, 867-880.
Nigam, R., Srivastava, S., Prakash, S., and Srivastava, M. M. (2000). Effect of organic acids on the availability of cadmium in wheat. Chem. Spec. Bioavailab. 12, 125-132. doi: 10.3184/095422900782775481

Nwugo, C. C., and Huerta, A. J. (2008). Effects of silicon nutrition on cadmium uptake, growth and photosynthesis of rice plants exposed to low-level cadmium. Plant Soil 311, 73-86. doi: 10.1007/s11104-008-9659-4

Nwugo, C. C., and Huerta, A. J. (2011). The effect of silicon on the leaf proteome of rice (Oryza sativa L.) plants under cadmium-stress. J. Proteome Res. 10, 518-528. doi: 10.1021/pr100716h

Pavlovic, J., Samardzic, J., Maksimovic, V., Timotijevic, G., Stevic, N., Laursen, K. H., et al. (2013). Silicon alleviates iron deficiency in cucumber by promoting mobilization of iron in the root apoplast. New Phytol. 198, 1096-1107. doi: 10.1111/nph.12213

Regvar, M., Eichert, D., Kaulich, B., Gianoncelli, A., Pongrac, P., and VogelMikus, K. (2013). Biochemical characterization of cell types within leaves of metal-hyperaccumulating Noccaea praecox (Brassicaceae). Plant Soil 373, 157-171. doi: 10.1007/s11104-013-1768-z

Rennenberg, H. (1980). Glutathione metabolism and possible biological roles in higher plants. Phytochemistry 21, 2771-2781. doi: 10.1016/00319422(80)85045-X

Rizwan, M., Meunier, J. D., Miche, H., and Keller, C. (2012). Effect of silicon on reducing cadmium toxicity in durum wheat (Triticum turgidum L. cv. Claudio W.) grown in a soil with aged contamination. J. Hazard Mater. 209-210, 326-334. doi: 10.1016/j.jhazmat.2012.01.033

Rodriguez-Hernandez, M. D., Moreno, D. A., Carvajal, M., and Ballesta, M. D. M. (2013). Interactive effects of boron and $\mathrm{NaCl}$ stress on water and nutrient transport in two broccoli cultivars. Funct. Plant Biol. 40, 739-748. doi: 10.1071/FP12314

Rogalla, H., and Römheld, V. (2002). Role of leaf apoplast in silicon-mediated manganese tolerance of Cucumis sativus L. Plant Cell Environ. 25, 549-555. doi: 10.1046/j.1365-3040.2002.00835.x

Salt, D. E., Prince, R. C., Pickering, I. J., and Raskin, I. (1995). Mechanisms of cadmium mobility and accumulation in Indian mustard. Plant Physiol. 109, 1427-1433.

Senden, M. H. M. N., van der Meer, A. J. G. M., Verburg, T. G., and Wolterbeek, H. T. (1995). Citric acid in tomato plant roots and its effect on cadmium uptake and distribution. Plant Soil 171, 333-339. doi: 10.1007/BF00010289

Shi, G. R., Cai, Q. S., Liu, C. F., and Wu, L. (2010). Silicon alleviates cadmium toxicity in peanut plants in relation to cadmium distribution and stimulation of antioxidative enzymes. Plant Growth Regul. 61, 45-52. doi: 10.1007/s10725010-9447-z

Shi, X. H., Zhang, C. C., Wang, H., and Zhang, F. S. (2005). Effect of Si on the distribution of Cd in rice seedlings. Plant Soil 272, 53-60. doi: 10.1007/s11104004-3920-2

Song, A., Li, Z., Zhang, J., Xue, G., Fan, F., and Liang, Y. (2009). Silicon-enhanced resistance to cadmium toxicity in Brassica chinensis L. is attributed to Si-suppressed cadmium uptake and transport and $\mathrm{Si}$ enhanced antioxidant defense capacity. J. Hazard. Mater. 172, 74-83. doi: 10.1016/j.jhazmat.2009.06.143

Stohs, S. J., and Bagchi, D. (1995). Oxidative mechanisms in the toxicity of metal ions. Free Radical Bio. Med. 18, 321-336. doi: 10.1016/0891-5849(94) 00159-H

Sun, R., Zhou, Q., and Wei, S. (2011). Cadmium accumulation in relation to organic acids and nonprotein thiols in leaves of the recently found Cd hyperaccumulator Rorippa globosa and the Cd-accumulating plant Rorippa islandica. J. Plant Growth Regul. 30, 83-91. doi: 10.1007/s00344-0109176-6

Tian, S., Lu, L., Labavitch, J., Yang, X., He, Z., Hu, H., et al. (2011). Cellular sequestration of cadmium in the hyperaccumulator plant species Sedum alfredii. Plant Physiol. 157, 1914-1925. doi: 10.1104/pp.111.183947

Tiryakioglu, M., Eker, S., Ozkutlu, F., Husted, S., and Cakmak, I. (2006). Antioxidant defense system and cadmium uptake in barley genotypes differing in cadmium tolerance. J. Trace Elem. Med. Biol. 20, 181-189. doi: 10.1016/j.jtemb.2005.12.004

Vaculík, M., Landberg, T., Greger, M., Luxova, M., Stolarikova, M., and Lux, A. (2012). Silicon modifies root anatomy, and uptake and subcellular distribution of cadmium in young maize plants. Ann. Bot. 110, 433-443. doi: $10.1093 / \mathrm{aob} / \mathrm{mcs} 039$ 
Vaculík, M., Lux, A., Luxová, M., Tanimoto, E., and Lichtscheidl, I. (2009). Silicon mitigates cadmium inhibitory effects in young maize plants. Environ. Exp. Bot. 67, 52-58. doi: 10.1016/j.envexpbot.2009.06.012

Vatehová, Z., Kollárová, K., Zelko, I., Richterová-Kučerová, D., Bujdoš, M., and Lišková, D. (2012). Interaction of silicon and cadmium in Brassica juncea and Brassica napus. Biologia 67, 498-504. doi: 10.2478/s11756-0120034-9

Velikova, V., Yordanov, I., and Edreva, A. (2000). Oxidative stress and some antioxidant systems in acid rain-treated bean plants - Protective role of exogenous polyamines. Plant Sci. 151, 59-66. doi: 10.1016/S01689452(99)00197-1

Wu, J. W., Shi, Y., Zhu, Y. X., Wang, Y. C., and Gong, H. J. (2013). Mechanisms of enhanced heavy metal tolerance in plants by silicon: a review. Pedosphere 23, 815-825. doi: 10.1016/S1002-0160(13)60073-9

Xu, J., Zhu, Y. Y., Ge, Q., Li, Y. L., Sun, J. H., Zhang, Y., et al. (2012). Comparative physiological responses of Solanum nigrum and Solanum torvum to cadmium stress. New Phytol. 196, 125-138. doi: 10.1111/j.1469-8137.2012. 04236.x

Yang, J. L., Zhu, X. F., Peng, Y. X., Zheng, C., Li, G. X., Liu, Y., et al. (2011). Cell wall hemicellulose contributes significantly to aluminum adsorption and root growth in Arabidopsis. Plant Physiol. 155, 1885-1892. doi: $10.1104 /$ pp.111.172221
Zhang, H., Xia, Y., Wang, G., and Shen, Z. (2008). Excess copper induces accumulation of hydrogen peroxide and increases lipid peroxidation and total activity of copper-zinc superoxide dismutase in roots of Elsholtzia haichowensis. Planta 227, 465 -475. doi: 10.1007/s00425-007-0632-x

Zheng, S. J., Lin, X. Y., Yang, J. L., Liu, Q., and Tang, C. X. (2004). The kinetics of aluminum adsorption and desorption by root cell walls of an aluminum resistant wheat (Triticum aestivum L.) cultivar. Plant Soil 261, 85-90. doi: 10.1023/B:PLSO.0000035576.71760.2b

Zhong, H., and Lauchli, A. (1993). Changes of cell wall composition and polymer size in primary roots of cotton seedlings under high salinity. J. Exp. Bot. 44, 773-778. doi: $10.1093 / \mathrm{jxb} / 44.4 .773$

Conflict of Interest Statement: The authors declare that the research was conducted in the absence of any commercial or financial relationships that could be construed as a potential conflict of interest.

Copyright (C) $2015 \mathrm{Wu}, \mathrm{Guo}, \mathrm{Hu}$ and Gong. This is an open-access article distributed under the terms of the Creative Commons Attribution License (CC BY). The use, distribution or reproduction in other forums is permitted, provided the original author(s) or licensor are credited and that the original publication in this journal is cited, in accordance with accepted academic practice. No use, distribution or reproduction is permitted which does not comply with these terms. 